1979

\title{
Necessitous Intervention: The Altruistic Intermeddler and the Law of Restitution
}

John D. McCamus

Osgoode Hall Law School of York University, jmccamus@osgoode.yorku.ca

Source Publication:

Ottawa Law Review. Volume 11, Number 2 (1979), p. 297-336.

Follow this and additional works at: https://digitalcommons.osgoode.yorku.ca/scholarly_works (c) (1) $(9)$

This work is licensed under a Creative Commons Attribution-Noncommercial-No Derivative Works 4.0 License.

\section{Recommended Citation}

McCamus, John D. "Necessitous Intervention: The Altruistic Intermeddler and the Law of Restitution." Ottawa Law Review 11.2 (1979): 297-336.

This Article is brought to you for free and open access by the Faculty Scholarship at Osgoode Digital Commons. It has been accepted for inclusion in Articles \& Book Chapters by an authorized administrator of Osgoode Digital Commons. 


\title{
NECESSITOUS INTERVENTION: THE ALTRUISTIC INTERMEDDLER AND THE LAW OF RESTITUTION
}

\author{
John D. McCamus*
}

\section{INTRODUCTION}

A person who responds in a selfless manner to another's necessitous circumstances by providing appropriate assistance will deserve, and will often receive, expressions of gratitude and esteem. The altruist is among the most cherished of our fellows. It is another matter. of course, whether altruistic interventions ought to give rise to a duty on the part of the recipient of such assistance to render compensation for the value of benefits received. In the past, the courts have evidenced some reluctance to grant recovery to the intervenor. especially where the benefit conferred consists of the preservation of another's property.' More recently, however, it seems to have been accepted as a general principle that one who. being an appropriate person to do so. responds to another's emergency by supplying (or by arranging at his own expense for the supply of) needed goods, services, or money, is entitled to restitution for the value of these benefits, provided that their conferral was not intended as a gift. For convenience. this general principle will be referred to here as the principle of necessitous intervention. It is the purpose of this article to explore the evidence to be found in the case law manifesting an acceptance of this principle and to suggest what appear to the writer to be fruitful lines of analysis in areas of the case law where the principle has not as yet been fully embraced.

The policy served by the necessitous intervention principle maly be that which is said to underlie the roughly analogous civilian doctrine, negotionum gestio. ${ }^{2}$ Recovery for the value of benefits conferred is permitted as a means

* Associate Professor of Law. Osgoode Hall Lau School. York Universily I would like to thank my colleague. Harry Glasbeeh. for his helpful comments on an carlier draft of this article.

${ }^{1}$ See pp. 315-20, infra.

2 For an account of the early history of this doctrine. se' $W$ BLCNI AND, $A$ TEXTBOOK OF ROMAN Lall 537-38 (3d ed. 1963): H Jolowic/. ANo B Nichol as, Historic al INTRODUCTION to the STUDY OF ROMAN Lall 298 (30 ed. 1972) For a detailed examination of the evolution of the doctrine in modern civilian jurisdictions. see Dawson. Negotiorum Gestio: The Altruistic Intermeddler. 74 HARV. L Rk1 817, 1073 (1961). 
of encouraging interventions which are perceived to be socially useful. ${ }^{3}$ An alternative and, arguably, preferable rationale is supplied by the principle of unjust enrichment which holds that one ought to pay for the value of benefits received at another's expense where it would be inequitable or "against conscience" to fail to do so. For some time, this has been recognized by the American courts ${ }^{4}$ to be the general theme which unifies the restitutionary case law, including the necessitous intervention cases, ${ }^{5}$ and provides a theoretical underpinning for the imposition of liability, which is distinct from the theories of obligation underlying the other major subjects of our private law, contract and tort. ${ }^{6}$ Following this American lead, the Supreme Court of Canada has expressly adopted the unjust enrichment principle as the juristic basis for much of what was formerly characterized as "quasi-contract" " and appears to have accepted, as do the Americans, that it also offers the proper explanation for liabilities imposed through the device of the constructive trust. ${ }^{8}$ It would, of course, be consistent with these developments (if, indeed, it is not dictated by them) to recognize that the recovery granted in the necessitous intervention cases is, in Canadian

${ }^{3} \mathrm{Cf}$. the following statement, taken from Justinian, setting forth the rationale for the doctrine of negotiorum gestio:

The reason of this is the general convenience; otherwise people might be summoned away by some sudden event of pressing importance, and without commissioning anyone to look after and manage their affairs, the result of which would be that during their absence those affairs would be entirely neglected; and of course no one would be likely to attend to them if he were to have no action for the recovery of any outlay he might have incurred in so doing.

See Justinian, Inst. lib. III, tit. xxvii, s. 1, quoted in Williston, Agency of Necessity, 22 CAN. B. Rev. 492, at 492-93, n. 4 (1944).

${ }^{4}$ See generally RESTATEMENT OF THE LAw OF RESTITUTION (1937) [hercinafter cited as Restitution]; G. Palmer, 1-4 The Law of Restitution (1978).

${ }^{5}$ See Restrtution, supra note 4, at ss. 112-17; PAlmer, supra note 4, at ch. 10; Wade, Restitution for Benefits Conferred Without Request, 19 VAND. L. REv. 1183 (1965-66).

${ }^{6}$ Contract serves the general policy objective of enforcing promises. It enforces voluntarily assumed promissory obligations and awards remedies calculated to give the promisee the promised performance (specific performance) or its equivalent in money (damages). Tort serves the policy of requiring wrongdoers to compensate for injurics caused by their conduct. It imposes an involuntary duty on wrongdoers to compensate their victims and measures compensable loss by the extent of the injury sustained by the plaintiff. Restitution serves the objective of preventing unjust enrichment. It imposes an involuntary duty to disgorge the value of the benefit received and measures its relicf in terms of the value of the benefit conferred on the defendant at the plaintiff's expense. Se' generally R. Goff AND G. Jones, THE LAw Of Restitution ch. 1 (2d ed. 1978).

${ }^{7}$ The critical authority is Deglman v. Guaranty Trust Co., [1954] S.C.R. 725 , [1954] 3 D.L.R. 785. See also Rural Municipality of Storthoaks v. Mobil Oil Canada Lid., [1976] 2 S.C.R. 147, 55 D.L.R. (3d) 1 (1975); County of Carleton v. City of Ottawa, [1965] S.C.R. 663, 52 D.L.R. (2d) 220. And see generally McCamus, Restitutionary Remedies, [1975] SPECIAL Lectures L.S.U.C. 255.

${ }^{8}$ See Rathwell v. Rathwell, [1978] 2 S.C.R. 436, [1978] 2 W.W.R. 101, 83 D.L.R. (3d) 289. See also McCamus and Taman, Rathwell v. Rathwell: Matrimonial Property. Resulting and Constructive Trusts, 16 Osgoode HALL L.J. 741 (1978). 
law at least, ${ }^{9}$ merely another instance of the application of the unjust enrichment principle.

As it may be considered doubtful that restitutionary liability rules are likely to have much impact in shaping the conduct of human affairs. the unjust enrichment rationale may provide a more secure foundation for the obligation imposed in the necessitous intervention cases than does the notion that recovery will encourage intervention of this kind. ${ }^{10}$ The moral sentiment captured by the unjust enrichment principle is simply that. as a general rule. it is perceived to be unjust that one party should gain a windfall benefit at another's expense, unless a gift was intended. "The hopeful thought that the granting of restitutionary relief might encourage altruism may provide additional support for the imposition of liability, but the unjust enrichment principle will be satisfied merely by the existence of an unintended "free ride".

The earlier reluctance of the courts to grant relief may have found its inspiration in the supposed general hostility of English law to recovery for benefits conferred in the absence of request. As Bowen L.J. said in his oft-quoted dictum in Falcke's case. "Liabilities are not to be forced upon people behind their backs any more than you can confer a benefit upon a man against his will. ${ }^{12}$ As others ${ }^{13}$ have pointed out, however, the extent to which the common law has acted on this sentiment is capable of exaggeration. Indeed, the necessitous intervention case law offers compelling evidence that English courts would, in appropriate cases, order compensation for the value of benefits conferred, even though the recipient

${ }^{9}$ In contrast to the Canadian position. English law has not yet clearly adopted the unjust enrichment principle as the juristic basis for restitutionary claims. See generally GOFF AND JONES. supra note 6.

${ }^{10}$ On the somewhat related question as 10 whether "Good Samaritan" slatutes are likely to have a positive influence in encouraging altruism. some authors have expressed optimism. See Dawson. Rewards for the Rescue of Human Life"?, in XXIII CENTLRY Comparative and Conflicts Lall 142 (K. Nadelmann et al. eds. 1961); Gray and Sharpe. Doctors, Samaritans and the Acciden Victim. 11 Oscoodr HA1 I L.J I (1973).

11 Thus. Dickson J.. in applying the principle in the context of matrimonal property disputes, said:

As a matter of principle. the court will not allow any man unjustly to appropriate to himself the value earned by the labours of another. That principle is not defeated by the existence of a matrimonial relationship beineen the parties: but. for the principle to succeed. the facts must display an enrichment. a corresponding deprivation. and the absence of any jurtstic reason - such as a contract or disposition of law - for the enrichment.

Rathwell v. Rathwell, supra note 8. at 455. [1978] 2 W.W.R. at 113-14.83 D.L.R. (3d) at 306. And see McCamus. The Self-Serving Intermeddler and the Low of Restutution, 16 OSGOOde Hall L.J. 515. at 522-23 (1978).

12 Falcke v. Scottish Imperial Ins. Co.. 34 Ch. D. 234. at 248, 56 L.J. Ch. 707, at 713 (C.A. 1886). Falcke's case. it should be noted. is not a case of necessitous intervention but rather that of a claim brought by one who. in pursuit of his own interest. incidentally confers a benefit on another. For discussion of this problem generally. and Falcke's case particularly, see McCamus. supra note 11.

${ }^{13}$ See especially. Birks. Negoriorum Gestio and the Common Law. 24 Cl hkt vi Lfo Prob. 110 (1971). 
had neither requested them nor acquiesced in their supply in the knowledge that compensation was expected. What has been lacking in the English jurisprudence on this point, however, is a clearly articulated basis for distinguishing cases in which relief is warranted from those in which it is not. One of the great contributions of modern restitutionary theory, first stated systematically in the American Restatement of Restitution, ${ }^{14}$ has been to provide an analytical device well suited to this task.

The fixation of at least some English courts on the notion of request as a critical factor may be explained, in part, by the ascendancy in English law of what is often referred to as the "implied contract" theory of restitutionary obligation. ${ }^{15}$ In the absence of an alternative theoretical explanation for the imposition of restitutionary duties, it was commonly assumed that liability would be imposed only where a contractual duty to pay could be implied in the circumstances of the particular case. Hence, the term "quasi-contract". In the absence of a request, or at least an acceptance of the benefit in the knowledge that payment was expected (a "free acceptance"), it may have appeared difficult to imply that a contractual duty to pay had been assumed. Although the evident artificiality of this implied contract doctrine has occasionally been noted with disfavour by English judges, ${ }^{16}$ it has not yet been completely exorcised from English restitutionary law in the way that it has been from American ${ }^{17}$ and Canadian doctrine. ${ }^{18}$ In the latter jurisdictions, it is clearly recognized that restitutionary obligations are not premised on voluntarily assumed contractual obligations which can be inferred from the circumstances, but rather are obligations imposed by law in order to prevent an unjust enrichment.

The desire to find evidence of an express or implied request cannot, however, be simply dismissed as a misguided attempt to force restitutionary doctrine into the Procrustean bed of contractual theory. Two concerns of a less scholastic nature also appear to underlie the hesitation to reward unrequested intervention. First, there appears to be some concern that a rule permitting recovery might encourage meddlesome intervention in another's affairs by persons who are acting malevolently or are imposing themselves on an individual who is, or may be, an unwilling beneficiary. ${ }^{19}$ Secondly, it may be considered unfair, as a general matter, to force individuals to pay for benefits which they did not freely choose. ${ }^{20}$ To allow recovery would offend a value, which is perhaps strongly held, that individuals ought generally to

${ }^{14}$ Supra note 4.

${ }^{15}$ See generally GoFF AND JoNES, supra note 6, at 5-11.

${ }^{16}$ See, e.g., Craven-Ellis v. Canons, Ltd., [1936] 2 K.B. 403, 105 L.J.K.B. 767 (C.A.); In re Rhodes, 44 Ch. D. 94, 59 L.J. Ch. 298 (C.A. 1890) (considered within, se' pp. 312-14, infra).

17 See materials cited note 4 supra.

${ }^{18}$ See materials cited note 7 supra.

${ }^{19}$ See, e.g.. Nicholson v. Chapman, 2 H. BI. 254, at 259, 126 E.R. 536, at 539 (C.P. 1793) (per Eyre C.J.).

${ }^{20}$ See, e.g., Leigh v. Dickeson, 15 Q.B.D. 60, 52 L.T. 790 (C.A. 1884). And see generally McCamus, supra note 11, at 519-22. 
be free to invest their assets as they see fit. The first concern relates to obnoxious conduct on the part of the intervenor: the second relates to the recipient's freedom of choice. In cases where a request or free acceptance can be found. it is obvious that both of these concerns are met. Both the intervenor and the form of the benefit have been freely chosen by the defendant. As suggested above. however. the use of request as a device for identifying cases in which recovery will be granted is not satisfactory. A rule based on request would fail us in at least two distinct senses. First, it could not explain the results of the decided cases. In particular, it could not account for the results in the necessitous intervention case law considered within. Secondly, a rule which denied recovery in all cases but those in which the benefits had been requested or freely accepted would go further than is necessary to meet the two concerns ariculated above. There will be many cases - and the necessitous intervention cases are prominent among these - where good faith intervention which is consistent with the recipient's concern to avoid investment in unwanted benefits is not accompanied by a request or free acceptance.

A more satisfactory analysis is offered by modern restitutionary doctrine. The general principles of the law of restitution direct us to consider both of these concerns more explicitly than would a rule premised on request or free acceptance. First. the Restatement sets forth as a general limitation on the right to recovery that it will be denied 10 one who has intervened officiously. ${ }^{21}$ Officious conduct is "interference in the affairs of others not justified by the circumstances under which the interference takes place." 22 Meddlesome intervention is thus attacked directly by the officiousness limitation rather than indirectly and inadequately through the use of a request requirement. Secondly, restitutionary recovery is premised on a finding that the defendant has received a genuine benefit. ${ }^{23}$ Judicious use of this concept will permit us to distinguish unrequested interventions which are truly of value to the defendant from those unwanted and irrecoverable benefits which he would not. if given an opportunity. have freely chosen.

In short. the concerns which appear to underlie the attitude of the common law typified by Bowen L.J.'s colourful invocation of the importance of request, are more directly and precisely addressed by the restitutionary concepts of officiousness and benefit. These concerns can be translated into the terms of modern restitutionary analysis in the following manner. If recovery is allowed for unrequested benefits, will officious intervention not be encouraged? Will the recipient not be forced to invest in benefits which he did not freely choose and which may not, therefore, constitute a genuine benefit to him? For purposes of the present discussion. however. we may note that both of these objections lose much of their force in the context of cases of necessitous intervention. One who intervenes helpfully in an emergency is probably not behaving officiously. If the

\footnotetext{
21 See Restitution. supra note 4. at s. 2.

22 Id. at s. 2. Comment a.

${ }^{23} \mathrm{Id}$. at s. I. And see McCamus. supra note 11 . at $519-22$
} 
intervention is officious, of course, recovery should be denied. Further, where the benefit supplied is one for which there is an immediate need, it will clearly constitute a benefit. Payment for its value may be seen as an expenditure which circumstances forced on the recipient rather than as an offensive intrusion on his freedom of choice by the intervenor. In the normal case, then, necessitous intervention will properly be characterized as the unofficious conferral of a genuine benefit. Accordingly, if the unjust enrichment analysis does indeed offer an explanation for the general outline of the existing case law, ${ }^{24}$ it should occasion no surprise that the courts do, in fact, often grant recovery in cases of necessitous intervention, even though the intervenor has not acted upon a request. So too, we should not be surprised if, on occasion, we find in the case law what now appear to be anomalous authorities denying relief on the basis that the intervention in question was uninvited.

Apart from the concern with the element of request, it may be that a secondary consideration underlying the apparent reluctance of the common law to adopt a general principle of necessitous intervention may rest in the moral sentiment, rarely expressed in the case law, that virtue is or ought to be its own reward. ${ }^{25}$ At least one judge has suggested, tentatively, that any more tangible reward should not be compelled by law. In Nicholson $v$. Chapman, ${ }^{26}$ Eyre C.J. questioned whether "it is better for the public that these voluntary acts of benevolence from one man to another, which are charities and moral duties, but not legal duties, should depend altogether for their reward upon the moral duty of gratitude." 27 Views of this kind are still reflected in the modern law to the extent that recovery is not allowed in cases where the intervenor has acted with a gratuitous intent. As a more general matter, however, the reluctance of the courts to reward unrequested intervention has, in this context, yielded to the rationales supporting recovery for the value of benefits conferred by the altruistic intervenor.

Though recognition of the necessitous intervention principle may now draw support from recent developments in restitutionary law, the growth of a body of law permitting recovery in specific instances of necessitous intervention substantially antedates the modern adoption of the unjust enrichment principle. One of the important sources of these rules is found in the evolution, during the nineteenth and early twentieth centuries, of the doctrine of agency of necessity. As in other areas of restitutionary law, however, the method of legal reasoning used to bring relief to the plaintiff was to strain established categories of legal obligation and develop rather artificial explanations for the imposition of liability in situations which can

${ }^{24}$ This would be one, but only one, of the criteria by which the success of the unjust enrichment principle as an organizing principle for this area of the law should be judged. For a stimulating and useful account of the role of legal conceptual schemes generally, and of the unjust enrichment principle in particular, see Samek, Unjust Enrichment, Quasi-contract and Restitution, 47 CAN B. REV. 1 (1969).

${ }^{25}$ See Allen, Legal Duties, 40 Y ALE L.J. 331, at 373-77 (1931).

${ }^{26}$ Supra note 19.

${ }^{27} I d$. 
now be more felicitously analyzed as instances of unjust enrichment. Thus the doctrine of agency of necessity. normally rooted in a pre-existing consensual relationship between the parties, was exiended by the courts to capture cases of necessitous intervention which cannot realistically be linked to an express or tacit consensus.

Before turning to consider the various instances of necessitous intervention recognized in the case law, the central features of the agency of necessity doctrine will be reviewed in an attempt to isolate its proper function and to distinguish from it the operation of the necessitous intervention principle.

\section{AGENCY OF NECESSITY Y 28}

The origins of this doctrine are found in a series of early nineteenth century cases holding that the master of a ship, acting in response to an emergency, had the authority, indeed the duty, to take reasonable steps to protect the ship, its crew, passengers and cargo. ${ }^{29}$ Provided that the master acted prudently and that it was impracticable for him to obtain appropriate instructions from the owner of the ship or cargo, the master would be entitled to reimbursement from the owner for the expenses incurred by him in carrying out these measures. ${ }^{30}$ Obviously such a rule meets the convenience of the owners. ${ }^{31}$ Further, in the case of conduct undertaken on behalf of the owner of the ship. it could reasonably be assumed by either party that such interventions are authorized, albeit tacitly, by the terms of the master's employment. ${ }^{32}$

The doctrine was later extended. notwithstanding the existence of some judicial opinion to the contrary. ${ }^{33}$ to cover agents carrying out assignments for their principals on land. In Greal Northern Railu'ay :. Swaffield, ${ }^{34}$ for example, a carrier who had placed a horse with a livery

${ }^{28}$ See generally Williston. supra note 3: G. FRIDMAN. THE Law of AGF.ser, ch. 12 (4th ed. 1976); R. Powell. The Lau of Agency ch. 9 (2d ed. 1961): S. Stol Jar. Thi LAW OF AGENCY ch. 7 (1961).

${ }^{29}$ Notara v. Henderson. L.R. 7 Q.B. 225. 41 L.J.Q.B. 158 (Ex. Ch. 1872) (statement of master's duty to take affirmative steps to preserve deteriorating cargo): Robertson v. Carruthers. 2 Stark. 571.17 I E.R. 739 (C.P. 1819) (sale of ship so damaged as not to be worth repairing): The Gratimudine. 3 C. Rob. 240, 165 E.R. 450 (H.C. of Adm. 1801) (Hypothecation of cargo for necessary repairs to ship). See generally Carver's Carriage by Sea 647 et seq. (12th ed. R. Colinvaux 1971 ).

${ }^{30}$ Cargo ex Agros, L.R. 5 P.C. 134, 28 L.T. 745 (1873).

${ }^{31}$ Id. at 165,28 L.T. at 756 (per Sir Montague Smith).

32 Though this point is rarely made explicit in the case las, it is evident that thus must be so. Otherwise. of course. it would be rather draconian to impose a dutv to att The implied authority to act in an emergency may thus be viewed as an extension to emergency situations of the general rule that the agent is presumed to have authority to perform any act which is necessary for and incidental to the effective execution of expressly authorized conduct. See Williston, supra note 3, at 494.

${ }^{33}$ See Hawtayne v. Bourne. 7 M. \& W. 595. at 599 (per Parke, B.). 600 (per Alderson B.), 10 L.J. Exch. 224, at 226 (1841): Guilliam r. Tu ist. [1895] 2 Q. B. 84, at 87. 64 L.J.Q.B. 474. at 478 (C.A.) (per Lord Esher).

${ }^{34}$ L.R. 9 Ex. 132. 43 L.J. Exch. 89 (1874). 
stable keeper when it was not met at its destination was held entitled to recover the cost of providing this necessary service. Similarly, it has been held that the employees of a railway may contract on their principal's behalf for necessary medical services for passengers injured in an accident. ${ }^{35}$ Further, it is established that a carrier may dispose of perishable goods in an emergency ${ }^{36}$ and there have been suggestions that this rule may be extended more generally to permit bailees in possession of another's goods to dispose of them in such circumstances. ${ }^{37}$

In cases where an existing agent assumes powers which would otherwise be beyond the scope of his authority in order to meet an emergency, the doctrine may operate merely as a reasoned elaboration of the terms of the agency relationship. ${ }^{38}$ Indeed, in such cases, the four conditions which are commonly said to be a prerequisite to the doctrine's application $^{39}$ may be viewed more straightforwardly as the essential features of an implied term which would reasonably be read into the agency agreement as being consistent with the presumed intent of the parties. The four conditions are the following:

(i) "it must be practically impossible to get the [principal's] instruction in time as to what shall be done"; ,0 $^{\text {in }}$

(ii) it must have been necessary for the agent to act as he did, though as onc judge explained, ${ }^{41}$ necessity ought not to be interpreted here as an

${ }^{35}$ Langan v. Great W. Ry., 30 L.T. 173 (Ex. Ch. 1873); Walker v. Great W. Ry.. L.R. 2 Ex. 228, 36 L.J. Exch. 123 (1867).

${ }^{36}$ See Springer v. Great W. Ry., [1921] 1 K.B. 257, [1920] All E.R. Rep. 361 (C.A. 1920); Sims \& Co. v. Midland Ry., [1913] 1 K.B. 103, 82 L.J.K.B. 67 (C.A. 1912).

${ }^{37}$ Coldman v. Hill, [1919] I K.B. 443, at 456, 120 L.T. 412, at 416 (C.A. 19i8) (per Scrutton L.J.). And see Sachs v. Miklos, [1948] 2 K.B. 23, [1948] I All E.R. 67 (C.A. 1947); Munro v. Willmott, [1949] 1 K.B. 295, [1948] 2 All E.R. 983 (1948) (holding, in each case, that no emergency has been established). But see further pp. 315-20, infra.

${ }^{38}$ The same may be said of certain bailments though this is, perhaps, less probable as the bailee's mandate is likely to be rather limited, and it may be a largely fictional excrcise to imply emergency powers. See Brown on Personal Property s. 11.10 (3d ed. W. Raushenbush 1975). Similarly, an authority to act in an emergency may, in appropriate circumstances, be implied in the context of a master-servant relationship. See Poland v. John Parr \& Sons, [1927] I K.B. 236, 96 L.J.K.B. 152 (C.A. 1926). The question of whether the master-servant relationship is to be considered as distinct from or rather as an instance of the agency relationship is a difficult one. See PoweLL, supra note 28, at 7-24. For present purposes, however, the distinction is immaterial inasmuch as the doctrine of agency of necessity has been applied to both "agents" and "servants".

${ }^{39}$ See generally Williston, supra note 3, at 497-501; GOFF AND JONES, supra note 6. at 266-67. And see Powell, supra note 28, at 429-32.

${ }^{40}$ Sims \& Co. v. Midland Ry., supra note 36, at 112,82 L.J.K.B. at 71 (per Scrutton J.) (semble). And see Bruton v. Regina City Policeman's Ass'n. [1945] 2 W.W.R. 273, at 295 (Sask. C.A.) (per Martin C.J.); The Margaret Mitchell, Swab. 382. 166 E.R. 1174 (H.C. of Adm. 1858); Tetley \& Co. v. British Trade Corp.. 10 L.L. Rep. 678 (K.B. 1922).

${ }^{41}$ Australasian Steam Navigation Co. v. Morse, L.R. 4 P.C. 222, at 230, 27 L.T. 357, at 359 (1872) (per Sir Montague Smith). And see Bank of New S. Wales v. Owston, 4 App. Cas. 270, at 290 (P.C. 1879), 48 L.J.P.C. 25, at 34 (per Sir Montague Smith). 
"irresistable compelling power" but rather as a situation of emergenc) which casts a duty on the agent to act in his principal's best interests;

(iii) the agent must have acted "bona fide in the interests of the partles concerned" $" ; 3$

(iv) the action taken must have been reasonable or prudent in the circumstances. ${ }^{44}$

Again, when the doctrine is applied in the context of an existing agency relationship, the substance of the matter will usually be that the parties are presumed, and reasonably so, to have tacitly agreed that if an unforeseen emergency should arise, the agent, being unable to communicate with the principal, would be empowered to act prudently in the latter's best interests. ${ }^{45}$ An agent faced with such circumstances would reasonably assume that he had such authority.

Further, it should be noted that in the cases of pre-existing agency, the emergency power of the agent of necessity is a power of a true agent. Thus, when exercised, it will have the usual consequences incidental to the exercise of an agent's powers. The agent may bind his principal in contract to a third party. ${ }^{46}$ The principal may be rendered vicariously liable in tort for actions taken in the emergency. ${ }^{47}$ The agent may be able to delegate his authority to act with the consequence that the principal may be exposed to vicarious liability for the tortious acts of the delegate. ${ }^{48}$ The agent, on the other hand, not being a mere stranger, may have a duty 10 act on his principal's behalf. ${ }^{49}$

There are two further consequences which flow from the principalagent relationship which are not, however, exclusive to it. First, and more importantly for present purposes, the agent is entitled to reimbursement

${ }^{42}$ See also John Koch. Ltd. v. C. \& H. Prods. Lid.. [1956] 2 Lloyd's Rep. 59, al 65 (C.A.) (per Singleton L.J.): Phelps. James \& Co. v. Hill. $|1891|$ । Q.B. 605. at 610, 60 L.J.Q.B. 382, at 384 (C.A.) (per Lindley L.J.).

${ }^{43}$ Prager v. Blatspiel. Stamp \& Heacock. Lid., [1924] । K.B. 566. at 572. 93 L.J.K.B. 410 , at 414 (per McCardie J.). See also Nova Scotia Marine Ins. Co. v L.P Churchill \& Co.. 26 S.C.R. 65 (1896): Tronson v. Dent. 8 Moo. P.C. 419. If E.R 159 (1853).

${ }^{44}$ Broom v. Hall. 7 C.B.. N.S. 503. I41 E.R. 911 (1859).

${ }^{45}$ Thus, the American rule is stated in the follow ing terms:

Unless otherwise agreed. if after authorization is given, an unforescen sttuation arises for which the terms of the authorization make no provision and it is impracticable for the agent to communicate with the principal. he is authorized to do what he reasonably believes to be necessary in order to prevent substantial loss to the principal with respect to the interests commilled to his charge.

See Restatement (Second) of Agency s. 47 (1958). See also J. Story, Agency ss $141-42$ (9th ed. 1882).

${ }^{46}$ See, e.g., Walker v. Great W. Ry. . supra note 35: Langan v. Great W. Ry. . supra note 35; Ledwell v. Charlottetown Light \& Power Co.. 13 E.L.R. 225 (P.E.I. C.A. 1913).

${ }^{47}$ Gwilliam v. Twist. [1895] ] Q.B. 557, 64 L.J.Q. B. 474. re' $d$ on the basis of lack of necessity, supra note 33 . But cf. Hollidge v. Duncan, 199 Mass. 121. 85 N.E. 186 (1908) (where Gwilliam v. Twist distinguished).

${ }^{48}$ Gwilliam v. Twist. supra note 47.

${ }^{49}$ See, e.g.. Cargo ex Argos. supra note 30: Langan $v$. Great W. R3 .. supra note 35 
from his principal. Secondly, conduct of the agent which would otherwise be considered tortious is, by virtue of being authorized, excused. As will be seen, the courts have applied similar rules of reimbursement and excuse, without relying on agency of necessity, to non-agents who have responded to another's emergency. It should be noted that the right to reimbursement ${ }^{30}$ is perhaps better recognized in this context than the tort privilege attaching to necessitous intervention. ${ }^{51} \mathrm{~A}$ clearly recognized juristic basis for applying these rules to non-agents has, however, been slow to develop. Accordingly, the courts have often drawn on an extended application of agency of necessity doctrine to supply a doctrinal basis for the importing of these two liability rules into cases of necessitous intervention by non-agents.

This phenomenon may be observed in the earliest stages of the doctrine's development. Indeed, Powell has suggested ${ }^{52}$ that this is true even of the shipmasters' cases. In Powell's view, the shipmaster who acts in an emergency on behalf of the owner of cargo is probably not acting in the course of an existing agency relationship with the cargo owner. The shipmaster's principal is the owner of the ship. It may be, however, that the results in many of these cases rest on terms genuinely implied in the charterparty agreement. ${ }^{53}$ More clearly artificial applications of the doctrine are evident in its use by the courts to provide a theoretical basis for the well-established right of indemnification of one who voluntarily discharges another's obligation on a negotiable instrument as an acceptor for honour ${ }^{54}$ and for the rule enabling a deserted wife to pledge her husband's credit. ${ }^{55}$ In neither instance does the situation lend itself to the inference of an implied power to deal with emergencies arising from the circumstances of a pre-existing agency relationship. The acceptor for honour may be a complete stranger to his alleged principal. The characterization of the relationship of separated spouses as that of principal and agent is an obvious fiction. ${ }^{56}$

\footnotetext{
${ }^{50}$ See generally text accompanying notes 73 et seq.. infra.

${ }^{51}$ See generally J. FLeming, THE LAw OF TORTS 92-96 (5th ed. 1977): A. LINDEN. CANAdian TORT LaW 70-72 (1977). And see further text accompanying notes 126-28. infra.

52 Powell, supra note 28, at 414. See also Fridman, supra note 28, at 120.

${ }^{53}$ Although the major uses of the doctrine in this context are: (i) to excuse the principal, the shipowner, from liability for what would otherwise be tortious conduct of his agent and (ii) to enable the shipowner who has, through the actions of his agent, incurred expense to recover therefor, the master's right to recovery has also been suggested. See Hingston v. Wendt, 1 Q.B. 367, at 370, 34 L.T. 181, at 182 (1876) (per Blackburn J.). It is possible that the results in cases (i) and (ii) may often be explained, without artificiality. on the basis that the charterparty tacitly confers emergency powers on the shipowner and permits delegation of their exercise to the master. The master's right of recovery does not. however, yield easily to this analysis.

${ }^{54}$ See Hawtayne v. Bourne, supra note 33. And see further text accompanying notes 135-39, infra.

${ }_{55}^{5}$ See, e.g., the dictum of Lush J. in Eastland v. Burchell, 3 Q.B.D. 432, at 436. 47 L.J.Q.B. 500, at 502 (1878). And see further text accompanying notes 169-74, infra.

${ }^{56}$ J.S. Ewart, in reviewing an edition of ANSON ON CONTRACT in which the agency of necessity rationale was accepted unquestioningly, sarcastically observed:
} 
More subtle departures from what might be termed the true agency model may also be observed. A Canadian case. Hastings $v$. Village of Semans,${ }^{57}$ offers a useful illustration. A woman seriously injured in an accident had been taken in the middle of the night to the office of a physician, one Dr. Hotham. Dr. Hotham put a temporary cast on her leg and took her to a private hospital in a nearby village. Ultimately the patient was found to be unable to pay and a claim was brought by the hospital against a second village in which she resided. Recovery was allowed on the following basis. As the patient was an indigent resident of the defendant village, the latter had a statutory duty to provide her with medical attendance and treatment. Further, and rather fortuitously, as Dr. Hotham was the defendant's medical officer, he was empowered as an agent of necessity to bring the patient to the plaintiff hospital for treatment. The defendant was therefore liable, presumably in contract, to the plaintiff hospital.

Though the imposition of liability for the services rendered in this case was quite appropriate, the reasoning of the court is questionable. It seems very doubtful that an emergency power to act on the municipality's behalf with respect to indigents would be viewed by the municipality as an incident of the medical health officer's role. ${ }^{58}$ Further, the report of the decision does not indicate any evidence to suggest that Dr. Hotham viewed himself as acting in the course of his duties as medical health officer at the time in question. A preferable explanation for the result, it is suggested, is that the plaintiff unofficiously benefited the defendant by fulfilling its statutory obligation to the indigent. Indeed, on this same hasis, $\mathrm{Dr}$. Hotham would be entitled to reimbursement from the village for the value of rendered services which fell outside his responsibilities as medical health officer ${ }^{59}$ and which, similarly. conferred a benefit on the village by fulfilling its statutory duty.

In short then, a clear distinction has not been drawn in the case law between cases of genuinely inferred powers of an agent to act in an emergency, and cases of necessitous intervention. The reason for this is easily discerned. In the absence of clear recognition of a principle of

I presume that the "necessity" is that of ascertaining some legal bass upon which to found liability: No man can be made liable for what neither he nor his agent orders: the deserted wife was not an agent: therefore - What? therefore the fact must be changed. and the wife must have been an agent $C$ an anything be more absurd?

33 HaRV. L. Rev. 626. at 627 (1920). See generally Powt1 supra note 28, al +25-28. Although agency of necessity is frequently adverted to in the Canadian authoritles, this is not invariably so. See, e.g.. Griffith v. Paterson, 20 Grant 615 (1873)

s. [1946] 3 W.W.R. 449. [1946] 4 D.L.R. 695 (Sask. C.A.)

${ }^{38}$ Dr. Hotham's duties were loosely defined to require him $"$ ' to look after the health of the people, infectious diseases particularly $\cdots$. Id. at 452 . [1946] + D.L.R. at 697

${ }^{59}$ If Dr. Hotham's duties were to include direct medical services to indigents (whether on a fee for service or some other basis) it is most improbable that this fact would not have been proven at trial in support of the plaintiff's relance on the agency of necessily doctrine. 
unjust enrichment upon which liability could be premised, it became necessary to strain the limits of orthodox agency theory to capture the necessitous intervention cases. Perhaps the most expansive view of the role of the agency of necessity doctrine was that suggested by McCardie J. in his well-known dictum in Prager $v$. Blatspiel, Stamp \& Heacock, Ltd. ${ }^{60}$ McCardie $J$. indicated that the doctrine could apply to a purchasing agent who might in war-time conditions find it necessary to resell goods originally purchased for his principal, and went on to say:

[T]here is nothing in the existing decisions which confines the agency of necessity to carriers whether by land or sea, or to the acceptors of bills of exchange. The basic principle I think is a broad and useful one. It lies at the root of the various classes of cases of which the carrier decisions are merely an illustration. ${ }^{61}$

Though it is far from clear that McCardie J. would have extended the doctrine to cover all cases of necessitous intervention, there is nothing in the judgment to suggest that the doctrine should be limited to cases where emergency powers could be implied into an existing agency agreement. As noted previously, the acceptor for honour would not meet this criterion and indeed, in Prager's case itself, the agency agreement would presumably have been nullified by the occupation of the principal's country of residence by enemy forces. The effect of the war on the agency agreement was not, however, expressly considered by McCardie J. in his judgment.

Other judges have attempted to restrict the scope of the doctrine to cases of pre-existing agency in which an implied power to act can, without artificiality, be implied. In Jebara v. Ottoman Bank ${ }^{62}$ for example, Scrutton L.J. responded to McCardie J.'s dictum in the following terms:

\begin{abstract}
The expansion desired by McCardie J. becomes less difficult when the agent of necessity develops from an original and subsisting agency, and only applics itself to unforeseen events not provided for in the original contract. . . . But the position seems quite different when there is no pre-existing agency as in the case of a tinder of perishable chattels or animals, and still more difficult when there is a pre-existing agency, but it has become illegal and void by reason of war, and the same reason will apply to invalidate any implied agency of necessity. ${ }^{63}$
\end{abstract}

It is not yet clearly established, however, whether these remarks offer an authoritative pronouncement on the proper scope of the doctrine and effectively confine what appears to be the more broadly conceived role envisaged for it by McCardie J.

The logic of the more restrictive view espoused by Scrutton L.J. appears particularly compelling when it is recalled that the actions of an agent of necessity may result in imposition of contractual and tortious

\footnotetext{
${ }^{60}$ Supra note 43.

${ }^{61}$ Id. at 570,93 L.J.K.B. at 413.

${ }^{62}$ [1927] 2 K.B. 254, 96 L.J.K.B. 581 (C.A.), rev'd on another ground, [1928]

${ }^{63} I d$. at 271,96 L.J.K.B. at 588.
}

A.C. 269 (H.L.). 
liability on the principal. To permit such consequences to flow from the actions of strangers to the principal would be inconsistent with the theory of obligation underlying these two branches of the law. On the other hand, an argument can be made against this narrow interpretation of the agency of necessity doctrine. The virtue of the approach advocated by $\mathrm{McC}$ ardie $\mathrm{J}$. is that it does provide a rule dressed in familiar terminological garb which will impose liability in at least some cases of necessitous intervention and this is, as will be seen, a liability which the courts have, in a considerable range of situations, been prepared to impose. True, the rationale for imposing liability in these cases is not an agency rationale. It is obviously a matter of rewarding unofficious intervention. If, however, emphasis is placed on the four conditions of the doctrine's application, ${ }^{\text {of }}$ recovery will be precluded where the intervention has been officious or imprudent. It might then be argued that without gross distortion of the doctrine, agency of necessity can perform serviceably as a framework of analysis for cases of necessitous intervention. To distinguish this application of the doctrine and avoid confusion with true cases of implied agency powers, one might refer to it as "quasi-agency". ${ }^{65}$

There are, however, a number of difficulties inherent in this expansive use of agency doctrine. First, in cases which approach the dividing line between true agency and quasi-agency, confusion concerning the rationale underlying relief may lead to the attribution of agency consequences to the conduct of persons who are not, in reality, agents of the principal. Secondly, as the facts of a particular case stray farther away from the true agency model, the agency roots of the liability rules may provoke unduly restrictive interpretations of their reach. This is especially so in cases of intervention by strangers ${ }^{66}$ but this problem may also arise in cases of pre-existing agency relationships. ${ }^{67}$ Finally, there are a number of instances of necessitous intervention in which liability has traditionally been imposed without reference to the agency of necessity doctrine. ${ }^{68}$ It is analytically cumbersome to preserve a distinction between cases of necessitous intervention which are to be explained as instances of

${ }^{64}$ See text accompanying notes $38-44$, supra.

65 A phrase coined by Ewart. See Ewart, supra note 56. at 627. See also Williston, supra note 3, at 501-02 (applying the phrase to the deserled wife cases).

${ }^{66}$ Consider, for example. the cases on preservation of property considered within. See pp. 315-20, infra. And see Jebara v. Ottoman Bank, supra note 62.

67 See, e.g., Scrutton L.J.'s criticism of Prager's case in Jebara v. Ottoman Bank. supra note 63. Cf. Re Banque des Marchands de Moscou (Koupetschesky), [1952] I All E.R. 1269, [1952] W.N. 151 (Ch.) (recovery not allowed for advantagcous legal services rendered for bank after its dissolution but before winding up. on the basis that the principal had ceased to exist), and contrast the American case law allowing recovery for services rendered to an estate prior to appointment of a personal representative, referred to in notes 115-17. infra.

${ }^{68}$ See, e.g., In re Rhodes, supra note 16 (necessaries supplied to a mental incompetent), considered at pp. 312-14, infra. Ambrose v. Kerrison, 10 C.B. 776, 138 E.R. 307 (C.P. 1851 ) (indemnification for burial expenses) considered al pp. 322-24, infra. 
quasi-agency and a further group which must be regarded merely as aberrations or, as is often suggested, as sporadic and unrelated importations into the common law of the civilian concept of negotiorum gestio. ${ }^{60}$

An analytical framework which would avoid these difficulties and therefore reduce the risk of inconsistent and anomalous decisions, would distinguish clearly between, on the one hand, cases of genuinely implied authority and, on the other, cases of necessitous intervention. The latter category would consist of interventions either by strangers or by agents acting in excess of any implied authority to act which could realistically be inferred from the circumstances. This approach has been adopted in American law. The use of agency doctrine is restricted to cases of implied authority ${ }^{\mathbf{7 0}}$ and from these are distinguished cases of necessitous intervention which are said to give rise to restitutional rights premised on the general principle of unjust enrichment. ${ }^{71}$

The adoption by Canadian courts of the unjust enrichment principle as the underlying rationale of so-called quasi-contractual liability ${ }^{72}$ permits a similar clarification of the theoretical foundations of these two related but distinct areas of our private law. When freed in this way from contrived connections to agency doctrine, the case law on necessitous intervention, to which we now turn, may be seen to yield a relatively coherent pattern of liability rules which emphasize a theme common to other areas of the modern law of restitution - the awarding of recovery to intervenors whose conduct is unofficious and has the effect of conferring a genuine benefit on the recipient.

\section{Necessitous INTERVENTION}

In this section, an account is given of instances of liability imposed for the value of benefits conferred in necessitous circumstances which cannot be rationalized on the basis of agency doctrines. Two categorics of liability may be distinguished: first, the liability of the person in need upon whom the benefit has been directly conferred; secondly, the liability of a third party whose duty to respond to another's emergency has been fulfilled by the intervenor.

${ }^{69}$ See, e.g., Powell, supra note 28, at 416-25; Marasinghe, The Place of Negotiorum Gestio in English Law, 8 OTtawA L. Rev. 573 (1976).

70 See Restatement (SeCOND) of AgEnCy, supra note 45.

${ }^{71} \mathrm{Id}$. at S. $14 \mathrm{I}$ :

A person who has a power created by law to subject another to liability for the protection of the other's person or property or for the performance of the other's obligations is not an agent but is the holder of a power to create restitutional rights. (emphasis added).

And see RESTITUTION, supra note 4, at ss. 112-17, especially s. 117(1).

${ }^{72}$ See text accompanying note 7 , supra. 


\title{
A. Intervention to Protect the Life, Health. Property or Credit of Another
}

\section{Preservation of Life or Health}

The provision of necessary medical or other rescue services 10 a person whose health or safety is in immediate peril presents a strong case for the granting of recovery. ${ }^{73}$ The provision of such services would normally be considered a benefit. And normally, interventions in such circumstances would be considered unofficious. Where the recipient of such services is unconscious or so irrational as to be unable to contract for their supply, it is evident that a successful claim for reimbursement or remuneration could only be explained in terms of restitutionary principles. ${ }^{74}$ In Matheson $v$. Smiley, ${ }^{75}$ the Manitoba Court of Appeal awarded recovery to a surgeon for attending a man who had attempted suicide. Robson J.A. commented in part:

\begin{abstract}
Smiley was conscious and did say something to plaintiff but it is clear that he was in such an extreme condition that no words of his then should be construed as a request for the plaintiff"s services or as an acquiescence in their being rendered on a contractual footing. . . . I think it is not within reason that even in such circumstances as are revealed here a person in such a plight should simply be allowed to die without an effort being made . . . to secure his recovery. . . . And surely the person to pay should be the person for whose benefil the service is rendered. ...

The common law takes notice of such emergencies and declares to be at duty what is almost invariably done upon human impulse is
\end{abstract}

The public interest in encouraging interventions of this kind is thus offered as a basis for overriding our general reluctance to award recovery for the value of unrequested services. No doubt a similar justification underlies the rule of tort law that a surgeon is not liable in tort for exceeding his patient's instructions in the course of an operation where he has, in the face of an unanticipated emergency, taken steps to preserve the patient's life or health. ${ }^{7 \pi}$

The fact that the services rendered in Matheson's case are ultimately unavailing is apparently not considered relevant. Success in the rescue effort is not a condition of recovery presumably for the reason that the

${ }^{73}$ See Restitution, supra note 4. at s. 116.

i4 See Matheson v. Smiley, 40 Man. R. 247. [1932] 2 D.L.R. 787 (C.A.). See also Cotnam v. Wisdom. 83 Ark. 601 . 104 S.W. 164 (1907) (recovers for services rendered b3 surgeon to an unconscious patient). Where the recipient is rational. however. his vieus would normally prevail. It may be. however. that $C$ anadian courts have been too acalous in applying this principle. In Mulloy v. Hop Sang. [1935] I W.W.R. 714 (Alta. C A.). a claim for the value of medical services rendered by a surgeon was disallowed as he had exceeded the patient's instructions. See also Soldiers Memorial Hosp. v Sanford, 7 M.P.R. 334. [1934] 2 D.L.R. 334 (N.S.S.C.) (disallowing a claim for hospital services rendered to an injured person. in the custody of police officers. Who had expressed an understandable preference for being taken to his own home).

is Supra note 74.

${ }^{76}$ Id. at 249. [1932] 2 D.L.R. at 789.

7 See Marshall v. Curry. 60 C.C.C. 136, at 152. [1933] 3 D.L.R. 260, at 275 (N.S.S.C.) (per Chisholm C.J.). 
defendant would, if rational, have wished that the attempt be made and would have authorized the expenditure involved.

Recovery would be precluded, of course, if it were established that the intervenor acted with the intention of making a gift. The fact that the intervenor was, in supplying the benefit concerned, acting in the course of his business or profession may be evidence of an intent to charge. ${ }^{78}$ Further, it is conceivable that an intervenor may expect reimbursement for out-of-pocket expenses even though he has no intention to charge for the value of his services. ${ }^{79}$

\section{The Supply of Necessaries to Mental Incompetents, Minors and Drunkards}

Even though mental incompetents, drunkards and minors suffer a general contractual incapacity, they may enter into binding contracts for the supply of necessaries. ${ }^{80}$ Where such agreements are, for some reason, unenforceable, a restitutionary claim for the value of necessaries which have actually been supplied will be available on the basis of restitutionary principles. ${ }^{81}$ Situations of this kind are not relevant to the theme of this paper. Our topic here is a consideration of the extent to which restitutionary liability is imposed for the value of necessaries supplied without request. As a general rule, such liability is imposed. The justification for this must rest on the necessitous intervention principle.

\section{(a) Mental Incompetents}

It is well established English ${ }^{82}$ and Canadian ${ }^{83}$ law that one who, without being requested to do so, unofficiously supplies necessaries to a mental incompetent is entitled to recover their value in a restitutionary claim. Thus in an early case, Williams $v$. Wentworth ${ }^{84}$ recovery was allowed against the estate of a mental incompetent for costs incurred by the plaintiff in petitioning for a commission of lunacy. This was said to be

${ }^{78}$ Restitution, supra note 4, at s. 114 , Comment c. It has been suggested that where it is customary to do so, account may be taken of the recipient's ability to pay in fixing the rate of remuneration. See Matheson v. Smiley, supra note 74. But see Cotnam v. Wisdom, supra note 74 .

${ }^{79}$ See GoFF AND JONES, supra note 6 , at 271-72.

${ }^{80} \mathrm{Id}$. at 343-64.

${ }^{81} \mathrm{Id}$. And see McCamus, Restitution of Benefits Conferred Under Minors' Contracts, 28 U.N.B.L.J. 89 (1979).

${ }^{82}$ See, e.g., In re Rhodes, supra note 16; Nelson v. Duncombe, 9 Beav. 211,50 E.R. 323 (Rolls Ct. 1846); Williams v. Wentworth, 5 Beav. 325, 49 E.R. 603 (Rolls Ct. 1842); Wentworth v. Tubb, 1 Y. \& C.C.C. 171, 62 E.R. 840 (V.C. 1841); Howard v. Earl Digby, 2 Cl. \& F. 634, 6 E.R. 1293 (H.C. of Ch. 1834).

${ }^{83}$ See, e.g., Morrow v. Morrow, 47 O.L.R. 222, 52 D.L.R. 628 (C.A. 1920); Re Mckeown, [1962] O.W.N. 142 (H.C.); Re Hilker, 55 O.L.R. 402 (H.C. 1924); East Hants Municipality v. Embree, [1948] 4 D.L.R. 151 (N.S. Cty. Ct.). And see Samilo v. Phillips, 69 D.L.R. (2d) 411 (B.C.S.C. 1968), rev'd as to counterclaim 18 D.L.R. (3d) 256n. (B.C.C.A. 1969), rev'd as to counterclaim [1972] S.C.R. 201 (1971).

${ }^{84}$ Supra note 82. 
"money expended for the necessary protection of the person and estate of the lunatic" 85 and, as such, could be the subject of a valid claim against the estate. Far from being requested, of course, such benefits may be conferred over the misguided protests of the recipient. ${ }^{86}$

That the rationale underlying the rule is restitutionary in nature, as opposed to being premised on notions of implied contract, cannot be doubted. In In re Rhodes, ${ }^{8 \pi}$ the Court of Appeal rejected the suggestion that liability ought not to be imposed on a party lacking contractual capacity. Cotton L.J. said:

[W] henever necessaries are supplied to a person who by reason of disability cannot himself contract, the law implies an obligation on the part of such person to pay for such necessaries out of his own properiy. It is asked, can there be an implied contract by a person who cannot himself contract in express terms? The answer is, that what the law implies on the part of such a person is an obligation, which has been improperly termed a contract. to repay money spent in supplying necessaries. ${ }^{88}$

Similar views were expressed by the other members of the court. ${ }^{89}$

Again, if the benefits were conferred with a gift intention, recovery would not be allowed. Indeed, it has been said that the intervenor must establish that he "intended at the time that he should be repaid". 90 This may be a difficult test for friends and relatives who respond to an emergency without directing much thought to the question of compensation but who, nonetheless, do not act with a clear intention to make a gift of the benefit conferred. ${ }^{91}$ Though such parties would perhaps not normally expect remuneration for their own exertions, it may be reasonable to assume that if they had been asked to address the question of reimbursement at the time of conferral, they would have articulated an assumption that they would be reimbursed, if possible. for out-of-pocket expenses. Accordingly, where such parties honestly profess that they had no clear thought on the matter at the time of conferral, it is arguably just that an award for such expenses be made. ${ }^{92}$ An alternative solution leading to a similar result would be to accept the suggestion of others ${ }^{93}$ that the

${ }^{85}$ Id. at 329,49 E.R. at 605.

${ }^{86}$ In Williams, the commission was contested but upheld upon the trial of a traverse. See also Matheson v. Smiley, supra note 74, discussed in accompanying text.

${ }^{8 \pi}$ In re Rhodes, supra note 16 (recovery disallowed on other grounds); see further text accompanying notes 90-94. infra.

${ }^{88}$ Id. at 105,59 L.J. Ch. at $302-03$.

${ }^{89}$ Id. at 107 (per Lindley L.J.). 108 (per Lopes L.J.), 59 L.J. Ch. at 303.

${ }^{90}$ Re Hilker, supra note 83. at 405 (per Rose J.). And see' In re Rhodes, supra nute 16.

${ }^{91}$ Few intervenors will be aware of the ir potential restitutionary claim at the ume of conferring the benefit. Those who are so aw are and who expect to rely on this entitlement will recover. See Re McKeown. supra note 83.

92 Compare the similar suggestion in the McKeown case that reimbursement should be afforded to parties who act "under a sense of duty or obligation and not merely gratuitously". id. at 145 .

${ }^{93}$ Goff AND Jones. supra note 6. at 271.275 (criticizing In re Rhades). 
onus should be placed on the recipient of the benefit to show that the supplier had no expectation of reimbursement. A gratuitous intent could, however, be inferred from circumstantial evidence, as where the intervenor manifests over a considerable period of time no interest in repayment. Such were the facts in In re Rhodes. In that case, relatives had paid part of the cost of maintaining a mentally incompetent woman in an asylum. The payments were made over a period of many years; no records were kept of the expenditures and no claim for reimbursement was made during her lifetime. The court concluded, in the words of Lopes L.J., that the payments were "bounteous gifts". ${ }^{94}$

\section{(b) Minors}

Similarly where an intervenor, being an appropriate person to do so, confers unrequested but necessary benefits upon a minor, liability on restitutionary grounds will be imposed. Although such situations may rarely arise, statements in support of this proposition are to be found in the case law ${ }^{95}$ and, indeed, liability has been imposed on this basis in a fcw instances. ${ }^{96}$

\section{(c) Drunkards}

An intervenor who supplies necessaries to one who is so intoxicated as to be incapable of rational assent to their supply may also invoke restitutionary principles. ${ }^{97}$ Thus recovery has been allowed for expenses incurred in caring for a man suffering from an attack of delirium tremens whose conduct had become violent and erratic. ${ }^{98}$ Given the temporary nature of drunkenness, however, it is unlikely that claims of this kind would involve necessaries other than emergency medical assistance and related services.

${ }^{94}$ Supra note 16 , at 108 .

${ }^{95}$ See, e.g., $\operatorname{Re~J.,~[1909]~I~Ch.~574,~at~577,~} 78$ L.J. Ch. 348, at 350 (C.A.) (per Fletcher Moulton L.J.): "In my opinion the position of a lunatic and that of an infant with regard to necessaries are precisely the same. Both come under the principle laid down authoritatively by the Court of Appeal in the case in In re Rhodes." And see Pontypridd Union v. Drew, [1927] 1 K.B. 2 14, at 220, 95 L.J.K.B. 1030, at 1034 (C.A. 1926) (per Scrutton L.J.).

${ }^{96}$ In re Oberth, 44 Man. R. 357, [1936] 3 W.W.R. 474 (K.B.); In re Clabbon. [1904] 2 Ch. 465,73 L.J. Ch. 853 . In both cases it may have been that the benefits were requested by the minor or his parent. If there was such a request in either case, however, it would have been made on the assumption that the benefits would not have to be paid for. Liability must therefore be premised on necessitous intervention rather than on the principles relating to ineffective transactions referred to in text accompanying note 81 , supra.

${ }^{97}$ See Gore v. Gibson, 13 M. \& W. 623, at 626 (per Pollock C.B.). 627 (per Alderson B.), 153 E.R. 260, at 262 (Ex. Ch. 1845).

98 West Ham Union v. Pearson, 62 L.T. 638 (C.A. 1890). It may be that delirium tremens is better viewed as a form of insanity. The defendant here was held not to be a lunatic and therefore not covered by the Lunacy Acts. He was held liable "simply upon the common law liability on the part of the defendant to repay the expenses necessarily incurred for the benefit of the defendant himself". Id. at 639 (per Fry L.J.). 


\section{Preservation of Property.}

Necessitous intervention to preserve the property of another has been less favourably treated than the categories previously considered. The problem has often arisen in the context of attempts by intervenors 10 assert a lien over property which has been saved or protected by their efforts. Such claims have been consistently rejected. ${ }^{99}$ In Nicholson $\because$. Chapman, ${ }^{100}$ for example, the defendant had rescued timber belonging to the plaintiff which had been carried away by the tide. The defendant refused to give up the timber unless the plaintiff would compensate him for the services rendered. In response to the plaintiff's claim in trover. the defendant, arguing for an extension of the rules of maritime law granting a possessory lien to salvors. ${ }^{101}$ claimed a lien against the timber. The owner's claim in trover succeeded. In dismissing the defendant's argument. Eyre C.J. emphasized that the owner would be placed in a very difficult situation if he were required to tender an uncertain amount in order to recover his goods. ${ }^{102}$ The rules of maritime salvage were distinguished as being rooted in a policy of encouraging the especially hazardous undertaking of rescue at sea. ${ }^{103}$

The question left at large in Nicholson. and indeed in the subsequent cases, is whether an intervenor might be entitled to in personam relief on the basis of necessitous intervention. Eyre C.J. was apparently sympathetic to such a claim:

This is a good office, and meritorious. at least in the moral sense of the word. and certainly intitles the party to some reasonable recompence from the bounly. if not from the justice of the ow ner: and of which. if a were refused, a court of justice would go as far as it could go. lowards enforcing the payment So tt would if a horse had strayed. . . [and] was tahen up b! some good-natured man and taken care of by him. till at some trouble. and perhaps at some expence, he had found out the owner. ${ }^{\text {int }}$

Nonetheless. Nicholson has been read as support for the general proposition that salvage on land must go unrew arded unless it has been rendered at the invitation. express or implied. of the ow ner. ${ }^{105}$ And though

${ }^{99}$ Fidelity Trust Co. v. Fenw ick. 51 O.L.R. 23. 64 D.L.R. 647 (H C 1921): Falche v. Scottish Imperial Ins. Co.. supra note 12: In re Leslic. 23 Ch. D 552. $52 \mathrm{~L}$.J Ch 762 (1883): Binstead v. Buck, 2 W. BI. 117. 96 E.R. 660 (1777): Nicholson v. Chapman, supra note 19.

${ }^{100}$ Supra note 19.

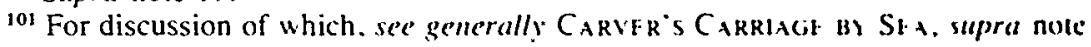
29. at 791-848: GOFF AND JONES. supra note 6. at 280-93

${ }^{102}$ Supra note 19.

${ }^{103}$ Id. at 257. 126 E.R. at 538. See also Falche v Scoutish Imperial Ins Co supra note 12. at 248-49. 56 L.J. Ch. at 714 (per Bowen L.J.)

${ }^{104}$ Supra note 19. at 258. 126 E.R. at 539.

${ }^{105}$ See, e.g., obiter dicra in The Gas Float Whitlon No 2. 11895$] \mathrm{P} 301$, at 311. rev'd [1896] P. 42 (C.A. 1895). aff d sub nom. Wells v. Gas Float Whiton No 2. [1897] A.C. 337 (H.L.): Aitchison v. Lohre. 4 App. Cas. 755 . at 760 (H L. 1879) (per Lord Blackburn). 
there does not appear to be an authority which directly so holds, there now exists a substantial body of dicta in support of this latter proposition. ${ }^{100}$

A right to in personam recovery has been recognized in other common law jurisdictions. In an Irish case, In re Pike, ${ }^{107}$ a claim was made against an estate for the value of services rendered by police constables who had protected the property of the deceased. In allowing the claim, Porter M.R. remarked:

[T] he police took the only reasonable and proper course in taking possession of the house and property themselves, as there was no one else to take charge of them. . . The claim, of course, cannot be based on contract - that is out of the question; but ... these constables have been the means of preserving. for the benefit of the persons now entitled to it, this large amount of property. . . . If this had been done by persons who were not policemen there can be no doubt about the power of the Court to direct payment of suitable remuneration. . . . ${ }^{108}$

The fact that the intervenors were police constables may lead one easily to the conclusion that the intervention was unofficious. Porter M.R. does suggest, however, that other good faith intervenors would be entitled to relief.

The American Restatement sets forth a general rule permitting recovery in cases of necessitous intervention to preserve property. ${ }^{109}$ Thus far, however, American courts have generally restricted recovery to cases in which a person has come into lawful possession of property, either as an agent of the owner or in some other fashion as an involuntary bailee, and then finds it necessary to take measures for its care and protection. ${ }^{110}$ Thus, recovery has been allowed to buyers of goods who have rightfully rescinded the agreement of sale, ${ }^{111}$ to lessors who protect property left on the premises by a departing lessee, ${ }^{112}$ and to finders who protect goods ultimately returned to their owners. ${ }^{113}$

There are some authorities which appear to stand apart from these limitations. In Berry v. Barbour ${ }^{114}$ recovery was granted to a repairman

106 The most colourful and influential of these is Bowen L.J.'s famous dictum in Falcke, supra note 103, which includes the statement quoted in text accompanying note 12, supra. Falcke concerns a payment made in pursuit of self-interest, rather than altruism. See generally McCamus, supra note 11.

10723 L.R. Ir. 9 (Ch. 1888). And see Allison v. Jenkins, [1904] I I.R. 341, at 348 (Ch. 1903) (per Sir Andrew Porter M.R.) (relying, by analogy, on the maritime principle of general average).

108 Supra note 107, at 11-12.

109 Restitution, supra note 4, at \$. 117(1).

${ }^{110}$ See generally PALMER, supra note 4, s. 10.3. And see Reporters' Notes on s. $117(1)$ in RESTITUTION, supra note 4.

111 Jones v. Healy, 237 App. Div. 264, 261 N.Y.S. 464 (1932); Truman's Pioneer Stud Farm v. Hansen, 108 Kan. 717, 196 P. 1087 (1921); Sapp v. Bradfield, 137 Ky. 308, 125 S.W. 721 (1910); Alexander v. Walker, 239 S.W. 309 (Tex. Ct. App. 1922).

112 Moline, Milburn \& Stoddard Co. v. Neville, 52 Neb. 574, 72 N.W. 854 (1897); Preston v. Neale, 78 Mass. (12 Gray) 222 (1858).

${ }^{113}$ Amory v. Flyn, 10 Johns. 102, 6 Am. Dec. 316 (N.Y. 1813); Chase v. Corcoran, 106 Mass. 286 (1871). Contra, Bryan v. Akers, 177 Ark. 681, 7 S.W. 2d 325 (1928):

Burns Motor Co. v. Briggs, 27 Ohio App. 80, 160 N.E. 728 (1928).

114137 Okla. 280, 279 P. 2d 335 (1954), noted in 53 Mich. L. RE V. 1013 (1955). 
who intervened in necessitous circumstances to repair the defendant's roof. The defendant had originally employed the plaintiff to effect roof repairs. During the course of this work, the building caught fire and the roof was partially destroyed. The defendant was, at this time, in Germany and the plaintiff, without seeking his consent, proceeded to repair the roof in order to prevent further damage to the building and its contents. It may be thought, however, that Berry v. Barbour does not constitute a substantial departure from the previous authorities, for there too the plaintiff may be seen to have had a special relationship to the property in question. A clearer break from the pre-existing relationship rationale is to be found in a series of cases awarding restitution where the property of a deceased person has been preserved pending the appointment of a personal representative. ${ }^{115}$ In some of these cases, the plaintiff has had a pre-existing relationship to the deceased. Thus, recovery has been granted to employees of a deceased who continued to look after his affairs until the appointment. ${ }^{116}$ In other cases, however, claims against the estate brought by third parties who had intervened in response to the requests of relatives and other members of the deceased's household have been successful. ${ }^{117}$

The difficult case, in America as in England, has been the fact situation exemplified by Nicholson v. Chapman, the claim of a stranger who intervenes to preserve property which has gone astray. and then seeks recompense for costs incurred in his rescue effort. There are a number of American cases denying in personam relief in these situations. ${ }^{118}$ The particular concern which may set these cases apart is a reluctance to develop a rule which might conceivably act as an incentive to malevolent intervenors who would first put the property in peril and then seek to be paid for its recovery. ${ }^{119}$ This is not a telling point however. To the extent that such concerns are realistic, they should be met by the burden which falls on the plaintiff to establish that his intervention was unofficious. 120 To deny relief in all such cases seems especially indefensible in the

115 See generall: Annot.. 108 A.L.R. 388 (1937).

${ }^{116}$ In re Bryant's Estate. $180 \mathrm{~Pa} .192 .36$ A. 738 (1897): Todd Y. Marun, + (al Unrep. 805, 37 P. 872 (1894). Contra. Mathie v. Hancock. 78 Vt. 414,63 A. 143 (1906).

117 Sibley Oil Co. v. Stein, 100 N.H. 356. 126 A. 2d 252 (1956); Wilder Grain Co. v. Felker, 296 Mass. 177, 5 N.E. 2d 207 (1936), noted in 36 MiCH. L. REv. 144 (1937).

${ }^{118}$ Kelley v. East Jordan Chemical Co.. 162 Mich. 525. 127 N.W 671 (1910); Glenn v. Savage. 14 Or. 567. 13 P. 442 (1887): Bartholomeu v. Jackson, 20 Johns. 28, 11 Am. Dec. 237 (N.Y. 1822). And see Merrill v. American Dock \& Trust Co., 13 N.Y.S 234 (1891). For a suggestion to the contrary. see Rrstituition, supra nole 4 , at s. $117(1)$, Comment b. Illustration 2.

119 See Note, supra note 114, at 1014. And see Nicholson v. Chapman, supra note 19 (indicating a concern to protect owners from "the wilful altempts of ill-designing people to turn their floats and vessels adrift. in order that they might be pand for finding them".).

${ }^{120}$ Professor Hope's remark is apposite: "[I]t is not to be reasonably anticipated that a policy thus carefully limited would breed overnight a nation of busy-bodies anxious to perform useless and meddlesome services for others and to try their luck with the courts". Hope, Officiousness, 15 CorNelL L.Q. 25. at 36 (1929). 
American context ${ }^{121}$ and it may be that this line of authority is approaching its eclipse. ${ }^{122}$ In the interim, however, it constitutes an obstacle to those who favour adoption of the general rule articulated in the Restatement. ${ }^{123}$

The only support to be found for a general rule allowing recovery in the Anglo-Canadian case law is indirect. We have seen that the doctrine of agency of necessity has been strained to capture what appear to be cases of necessitous intervention. ${ }^{124}$ Similarly, there is some evidence to suggest that the courts will not be reluctant to infer a request in situations where such intervention occurs. ${ }^{125}$ The policy underlying the necessitous intervention principle is also reflected in the rules of tort law relating to trespassers and involuntary bailees. In both cases, conduct which would otherwise be tortious will be excused if it amounts to a necessary and reasonable intervention to protect another's property. Thus, one may enter another's land and commit what would otherwise be a trespass if this conduct was reasonably necessary to protect the owner's property. ${ }^{126}$ The trespasser will not be excused, however, if his conduct is officious. ${ }^{127}$

121 The inconsistency is highlighted in Chase v. Corcoran, supra note 113 , in which the plaintiff failed to recover the cost of rescuing a boat which had gone adrift but was allowed recovery for the value of subsequently effected repairs and storage.

122 The reasoning in these cases typically draws support from notions now discredited in the other necessitous intervention authorities: (i) that liability for services rendered will be imposed only where they are in response to an express or implied request: sec. e.g.. Wadleigh v. Katahdin Pulp \& Paper Co., 116 Me. 107, 100 A. 150 (1917): Burns Motor Co. v. Briggs, supra note 113; Bryan v. Akers, supra note 113; (ii) that such intervenors are mere volunteers: see, e.g., Morse v. Kenney, 87 Vt. 445, 89 A. 865 (1914); Mathic v. Hancock, supra note 116; (iii) that services rendered in an emergency are deemed by law to be gratuitous: see, e.g., Glenn v. Savage, supra note 118, Bartholomew v. Jackson, supra note 118. As to the latter point, see Hope, supra note 120, at 36-37; PALMEk, supra note 4 , at s. $10.3,369$.

${ }^{123}$ See generally PALMER, supra note 4 , at chs. 6-12.

${ }^{124}$ See text accompanying notes 51-72, supra. And see Palmer v. Stear, 113 L. Jo. 420 (Cty. Ct. 1962) holding that a veterinary surgeon who intervened in an emergency to destroy a seriously injured dog had acted as an agent of necessity.

${ }^{125}$ See, e.g., Evans v. Schneider, 66 D.L.R. 758 (Alta. C.A. 1922) (negotiations for sale of cattle fail, potential buyer in possession recovers cost of feeding the caltle on the basis of an implied request).

${ }^{126}$ Sherrin v. Haggerty, [1953] O.W.N. 962 (Cty. Ct.); Cope v. Sharpe (No. 2). [1912] 1 K.B. 496, 81 L.J.K.B. 281 (C.A. 1911); Kirk v. Gregory, 1 Ex. 55, 45 L.J.Q.B. 186 (1876). One who trespasses to protect his own property will also, it scems. be excused. See Manor \& Co. v. M.V. "Sir John Crosbie", 52 D.L.R. (2d) 48 (Ex. 1965). aff'd sub nom. Munn \& Co. v. M.V. Sir John Crosbie, [1967] I Ex. C.R. 94 (1966). In the latter situation, of course, the argument for restitutionary compensation of the involuntary benefactor is especially compelling. Nonetheless, it has thus far been recognized only in the American case law. See Vincent v. Lake Erie Transp. Co.. 109 Minn. 456, 124 N.W. 221 (1910); Restitution, supra note 4, at s. 122. And s'c' Sussmann, The Defence of Private Necessity and the Problem of Compensation. 2 OTTAwA L. REv. 184 (1967).

${ }^{127}$ Kirk v. Gregory, supra note 126; Sherrin v. Haggerty, supra note 126 . In the latter case, the owner had been notified of an impending hazard and had chosen to do nothing. The intervenor was therefore liable in trespass and unsuccessful in a restitutionary counterclaim. 
Similarly, an involuntary bailee who acts reasonably in disposing of another's goods will not be guilty of conversion. ${ }^{128}$

In sum then, there is little support for the view that in personam recovery in these cases will be allowed by English or Canadian courts. Indeed, there is a body of dicta to the contrary. ${ }^{129}$ This apparent reluctance to reward necessitous intervention which preserves the property of another is, it is argued, anomalous and should be reviewed in the light of modern developments in restitutionary law. Support may be drawn for this view from a dictum of Laskin J.A. (as he then was) in Regina 1 . How'son. ${ }^{130}$ The accused had been charged with theft, after towing away the complainants car and refusing to release it unless towing charges were paid. The owner of property on which the complainant's car was improperly parked had requested this intervention. A defence based on "colour of right" was successful but the court indicated that a lien for the value of such services would not be allowed. Laskin J.A. did suggest, however, that an involuntary bailee ought in such circumstances to be entitled to an in personam remedy:

If he ... decides to remove it to an accessible place of safekeeping. I would hold that he should be entitled to recover the reasonable expenses incurred in doing so. Such a view may not be quite consonant with the attitude of the common law that a person cannot ordinarily be made a debtor without his consent: See Falcke v. Scottish Imperial Ins. Co. . . . But I pray in aid the expansion of the law of quasi-contract or restitution to suppor recognition of a legal obligation to reimburse a person who has thus taken care of another's goods which have been thrust upon him: See Fibrosa Spolka Akcyma . Fairbairn Lau'son Combe Barbour. Lid. . . . Deglman r. Guuranty Trust Co. of Canada and Constantineau. . . . ${ }^{131}$

It would be consistent, at least, with these views to hold that one who has intervened in an emergency ought similarly to be entitled to reimbursement.

The recognition of a general right to recover for necessitous intervention should, of course, be accompanied by the usual limitations to ensure that intervenors who act officiously will not be rewarded. ${ }^{132}$ Recovery should be denied where the intervenor failed to make reasonable attempts to communicate with the owner or had reason to believe that the owner did not wish him to act. Further, one who has acted with gratuitous

${ }^{128}$ Elvin \& Powell Ltd. v. Plummer Roddis. Lid., 50 T.L.R. 158 (K.B. 1933). See also Heugh v. London \& N.W. Ry., L.R. 5 Ex. 51,39 L.J. Exch. 48 (1870): McKean v. McIvor, L.R. 6 Ex. 36. 40 L.J. Exch. 30 (1870). But see Hiort v. Bolt, L.R. 9 Ex 86, 43 L.J. Exch. 81 (1874). And see generally Bronn on Personal. Property, supra note 38. at 319-31; G. Paton. Bailment in the Common Lall 114-17 (1952); Burnett, Conversion by an Involuntary Bailee. 76 L.Q.R. 364 (1960). A more general privilege to interfere with another's chattels in cases of emergency is suggested in the RESTATFMENT (SECOND) OF TORTS S. 262-63 (1965).

${ }^{129}$ See, e.g., Sorrell v. Paget. [1950] I K.B. 252. at 260. [19.49] 2 All E.R. 609, at 612 (C.A. 1949) (per Bucknill L.J.). And see cases cited notes 105-06, supra

${ }^{130}$ [1966] 2 O.R. 63, 55 D.L.R. (2d) 582 (C.A.).

${ }^{131}$ Id. at 74. 55 D.L.R. (2d) at 593.

${ }^{132}$ See generally Restitution. supra note 4. at s. 117. 
intent would not be permitted to convert his gift into a claim for compensation. ${ }^{133}$ Finally, as these benefits are unrequested, it will be necessary to ensure that the service rendered is one which is truly of value to the owner of the property in question. This would normally be established by demonstrating that the intervention was a reasonable response to an emergency and that the owner wishes to continue to assert his dominion over the property. ${ }^{134}$

\section{Preservation of Credit}

Where payment of another's debt is made in an attempt to preserve the debtor's commercial credit, the intervenor is clearly one who has conferred an unequivocal benefit in necessitous circumstances. The substitution of the intervenor as the new creditor is not likely to be prejudicial ${ }^{135}$ and the payment of the debt itself is an obligation which, presumably, the debtor originally assumed willingly. Provided that the intervention is unofficious, ${ }^{136}$ the imposition of a restitutionary duty to reimburse the intervenor thus seems appropriate.

This view is reflected in the rules of the law of negotiable instruments relating to the acceptor for honour. ${ }^{137}$ If a bill of exchange has been protested for dishonour by non-acceptance or for better security, any person who is not already a party to the bill may, with the consent of the holder, accept the bill for the honour of any party already liable on the bill, or for the honour of the drawer. ${ }^{138}$ If the acceptor for honour is ultimately required to pay the bill, he is then subrogated to the rights and duties of the holder with respect to the party for whose honour he pays and all partics liable to that party. ${ }^{139}$ Thus, even though the party whose liability has been discharged by the payment did not request this kindly intervention, an obligation to reimburse the intervenor is imposed.

Whether there exists a general duty, apart from the negotiable instruments cases, to reimburse a third party who pays another's debt is a

${ }^{133}$ See pp. 297-303, supra. Professor Woodward suggested that acts of necessitous intervention to preserve property should be deemed gratuitous. See F. Woodward, THE Law of QuaSi-Contracts s. 207 (1913). And see Glenn v. Savage, supra note 118. This view is generally considered unsound and ought, in my view, to be rejected. See Hope, supra note 120, at 36-38; PALMER, supra note 4, s. 10.3, at 370 .

${ }^{134}$ It is possible to conceive of situations - as where the preserved property had been abandoned and the owner now disclaims ownership - in which the service rendered should not be considered to constitute a benefit.

${ }^{135}$ Hence the debt is normally assignable. See generally CHESHIRE AND FIfoot's Law of Contract 493-515 (9th ed. M. Furmston 1976); G. Fridman. The Law of Contract in Canada 429-52 (1976); G. Treitel, The law of Contract $451-80$ (4th ed. 1975).

${ }^{136}$ For an illustration of officiousness in this context, see Norton v. Haggett, $117 \mathrm{Vt}$. 130, 85 A. 2d 571 (1952). And see McCamus, supra note 11, at 552-53.

${ }^{137}$ See generally ByLES on Bills 99-100, 121 (23d ed. M. Megrah \& F. Ryder 1965); Falconbridge on Banking and Bills of Exchange ch. 57 (7th ed. A. Rogers 1969). And see Restitution, supra note 4, at s. 117(2).

${ }^{138}$ The Bills of Exchange Act, R.S.C. 1970 , c. B-5, s. 147.

139 The Bills of Exchange Act, R.S.C. 1970, c. B-5, s. 155. 
much more difficult question. There is some support in the case law for the view that an intervenor who pays off another's debt in order to protect his own credit position is entitled to reimbursement. ${ }^{140}$ One might argue that if this is so, one who intervenes in good faith to protect the debtor's position ought, a fortiori, to be entitled to relief. Nonetheless, the courts have indicated some reluctance to permit recovery in such cases. ${ }^{141}$ Two reasons are commonly given for this. First, it is sometimes said that mere payment of another's debt does not discharge the debt. ${ }^{142}$ If this is so, mere payment does not have the effect of conferring a benefit. Secondly, it is said that intervenors in such circumstances are mere volunteers and, as such, ought not to be given a right to reimbursement. ${ }^{1+3}$ In my view, neither of these reasons is sound. I have argued elsewhere for a reconsideration of the rule denying relief in the context of claims brought by intervenors acting in their own self-interest. ${ }^{144}$ Provided that such parties have acted unofficiously and that the debtor is not prejudiced by the substitution of a new creditor, it is arguably unjust that the debtor should be enriched at the intervenor's expense. The unofficious intervenor ought not to be dismissed as a mere volunteer. The debt should be considered discharged unless subsequent events indicate that the creditor does not accept or act on this view. ${ }^{145}$ Whatever the merits of that position, however, the arguments favouring recovery seem all the more persuasive in the context of altruistic intervention. Certainly it would be consistent with the general thrust of the necessitous intervention case law to hold that such conduct ought to be rewarded by reimbursement and this, indeed, appears to have been accepted recently by the English Court of Appeal as the proper view. ${ }^{146}$ No doubt. the range of fact situations in which

${ }^{140}$ See Butler v. Rice. [1910] 2 Ch. 277. 79 L.J. Ch. 652.

${ }^{141}$ See, e.g.. In re Cleadon Trust. Lid.. [1939] Ch. 286, [19.38] + All E.R 518 (C.A. 1938). And see McCamus, supra note 11 at 554-58.

${ }^{142}$ See Lucas v. Wilkinson. 1 H. \& N. 420. 156 E.R. 1265 (Ex. 1856); Simpson v. Eggington. 10 Ex. 845. 156 E.R. 683 (1856): Belshaw v. Bush. II C.B. 191. 138 E.R 444 (1851). See Birks \& Beatson. Unrequested Payment of Another's Debr, 92 L.Q.R. 188 (1976). But see Hirachand Punamchand v. Temple. [1911] 2 K.B. 330,80 L.J.K.B. 1155 (C.A.); Cook v. Lister, 13 C.B.. N.S, 543 (1863): Pellatt v. Boosey. 8 Jur N S 1107, 31 L.J.C.P. 281 (1862). And see S. Stoljar. THE Lall of QList-Contract 143-44 (1964). For a discussion of the competing views on this question. see MiCamus, supra note 11 , at 557-58.

${ }_{143}$ See, e.g.. In re Cleadon Trust. Lid.. supra note 141.

${ }^{144}$ See McCamus, supra note 11 . at 550-58.

${ }^{145}$ For elaboration of this point. see id. at 558 .

${ }^{146}$ See the dictum of Scarman L.J. in Owen v. Tate. [1975] 2 All E. R. 129. at 134. [1975] 3 W.L.R. 369. at 375 (C.A. 1974): “|T]he fundamental question is whether in the circumstances it was reasonably necessary in the interest of the volunteer or the person for whom the payment was made. or both. that the payment should be made - whether in the circumstances it was "just and reasonable" that a right of reimbursement should artse." See also per Stephenson L.J. at 136. [1975] 3 W.L.R. at 378: In re' a Debtor. [1937] I Ch. 156. at 166, [1937] 1 All E.R. 1. at 10 (C.A. 1936) (per Greene L.J.); Anson v. Anson. [1953] I Q.B. 636. at 642-43. [1953] I All E.R. 867, at 869-70 (per Pearson J.) Adopting this view should carry with it the implication that the debt is discharged by the creditor's acceptance of the payment as a discharge. See Birks \& Beatson, supra note 142, at 201.207. 
recovery would be allowed will be very narrow, as it will normally be the case that the debtor can be contacted and his consent secured. Where this is not so, however, and where the intervenor is moved to act, for example, to save the debtor from forfeiture of property or an acceleration of interest charges, there appears to be a compelling case for restitutionary relief. ${ }^{147}$

\section{B. Fulfilment of Another's Duty}

\section{Fulfilment of Another's Duty to Bury the Dead}

The primary responsibility for the burial of a deceased person falls upon his personal representatives who are, in turn, entitled to be indemnified for these expenses from the estate as a first charge. ${ }^{148}$ The common law also establishes that other parties may have a secondary duty to bury, which may become operative if the estate is inadequate to bear this burden. Thus, it is the duty of the surviving spouse to bury the deceased. ${ }^{149}$ Indeed, prior to the enactment of married women's property legislation, ${ }^{150}$ the husband was primarily responsible for the burial of his deceased wife at common law. ${ }^{151}$ With the enactment of this legislation, however, the rationale for the common law rule disappeared and it was ultimately held that the primary burden was to be assumed by the deceased's estate. ${ }^{152}$ Further, it has been said that a parent, if of sufficient

${ }^{147}$ Cf. Drager v. Allison, 13 D.L.R. (2d) 204 (Sask. C.A. 1958). A father had paid off a mortgage debt before it was due in order to save the mortgagor children from interest charges. The house was subsequently resold by the children, who refused to reimburse the father. At trial it was held that the father recovered in unjust enrichment. The trial judge was reversed in the Court of Appeal, but was affirmed, on other grounds, by the Supreme Court of Canada: [1959] S.C.R. 661, 19 D.L.R. (2d) 431.

${ }^{148} 3$ Co. Inst. 202. See Schara Tzedeck-v. The Royal Trust Co., [1953] I S.C.R. 31, [1952] 4 D.L.R. 529; Edwards v. Edwards, 2 C. \& M. 612, 149 E.R. 905 (Ex. 1834). See generally WidDifield on Executors' Accounts ch. 1 (5th ed. F. Baker 1967).

149 Annot., 2 C.C.C. 257 (1899).

${ }^{150}$ Married Women's Property Act, 1882, 45 \& 46 Vict., c. 75. See generally Cullity, Property Rights During the Subsistence of Marriage, in Studies IN CANadian Family Law 179 (D. Mendes da Costa ed. 1972).

${ }^{151}$ Bradshaw v. Beard, 12 C.B., N.S. 344, 142 E.R. 1175 (C.P. 1862); Ambrose v. Kerrison, supra note 68 . The duty obtains even though they be separated: Routtu v. Routtu, 35 M.P.R. 94, [1955] 1 D.L.R. 627 (N.B. Cty. Ct. 1954); Jenkins v. Tucker, 1 H. BI. 90,126 E.R. 55 (C.P. 1788).

${ }^{152}$ Rees v. Hughes, [1946] 1 K.B. 517, [1946] 2 All E.R. 47 (C.A.). It is established that a husband who is also an executor or administrator may reimburse himself from the estate. In re Estate of Mailman, 15 M.P.R. 169, [1940] 2 D.L.R. 721 (N.S.S.C. in Banco), aff'd on other grounds [1941] S.C.R. 368; Re Asma, [1950] O.W.N. 291 (Surr. Ct.); In re M'Myn, 33 Ch. D. 575, 55 L.J. Ch. 845 (1886). Contra, Re Montgomery, 20 Man. R. 444, 17 W.L.R. 77 (K.B. 1911); Re Sea, 11 B.C.R. 324, 1 W.L.R. 460 (S.C. Chambers 1905). The claim of a husband who was not appointed administrator was disallowed, however, in $R e$ Spencer, [1955] O.W.N. 325, [1955] 4 D.L.R. 221 (Surr. (t.). The better view is that expressed in obiter dictum by Weatherston J.A. in Pearce v. Diensthuber, 17 O.R. (2d) 401, at 402, 81 D.L.R. (3d) 286, at 288 (C.A. 1977):

The logic of the matter leads one to conclude that the primary responsibility for the wife's funeral expenses is now on the executor or administrator, and that if the husband pays first, which according to common practice and decency he 
means, is responsible for the burial of a deceased child. ${ }^{153}$ In the case of a married child, the duty of the surviving spouse is of a higher order and the parents are entitled to seek from the survivor indemnification of such costs as cannot be borne by the estate. ${ }^{154}$ As well, it has been suggested that a common law duty to bury is imposed upon the owner of the premises in which the deceased has died. ${ }^{155}$

Finally, it must be noted that a statutory duty is commonly imposed on municipalities to bury an unclaimed body found within their limits. ${ }^{156}$ Typically, the statutory duty is residual in nature in the sense that indemnification from those having a common law duty to bury will be allowed. ${ }^{157 .}$

Restitutionary claims for reasonable expenses ${ }^{158}$ may arise where one with a secondary duty seeks indemnification from the estate. ${ }^{159}$ or from one with a higher duty. ${ }^{160}$ As well, successful claims may lie where a friend, relative or stranger ${ }^{161}$ has intervened in a responsible fashion. Indeed, an undertaker who has been invited by a stranger to the deceased to supply services will have a direct claim against the estate. ${ }^{162}$

usually must do. he is entitled to reimbursement out of his wife's estale, to the extent that assets are available.

And see, to the same effect. WoOdW ARD, supra note 133. at s. 206.

${ }_{153}$ Regina v. Newcomb. 2 C.C.C. 255 (N.S. C1y. Ci. 1898): Clark v. London Gen. Omnibus Co., [1906] 2 K.B. 648. 75 L.J.K.B. 907 (C.A.): Regina v. Vann, 2 Den. 325. 169 E.R. 523 (Q. Sess. 1851).

${ }^{154}$ Pearce v. Diensthuber. supra note 152. at 402.81 D.L.R. (3d) at 287-88.

${ }^{155}$ Regina v. Stewart. 12 Ad. \& E. 773. 113 E.R. 1007 (Q.B. 1840); Regina v. Newcomb, supra note 153.

${ }^{156}$ See, e.g., The Anatomy Act. R.S.O. 1970. c. 21. s. 11.

is The Anatomy Act, R.S.O. 1970. c. 21. s. 11. And see Davey $v$. Rural Municipality of Cornwallis, 39 Man. R. 259. at 263. [1931] 2 D.L.R. 80, at 83-84 (C.A.) (per Robson J.A.) suggesting that under similar Manituba provisions the municipaluty might be able to recover against the owner of premises in which a person is found dead even though the statute did not expressly so provide.

${ }_{158}$ The expense may not exceed what is suitable to the deceased's circumstances: Tugwell v. Heyman. 3 Camp. 298. 170 E.R. 1389 (K.B. 1812). It is, however. legitimate to act in accord with the wishes of the deceased: McDougall \& Brown Lid. v. Breckon. [1943] O.W.N. 705 (Cty. Ct.). See generall! Widdiftt1.D, supra note 148, at 4-8.

${ }^{159}$ See, e.g., cases which allow recovery by surviving husband against the estate, at note 152. supra.

${ }_{160}$ See, e.g.. Pearce v. Diensthuber, supra note 152 (parents recovering from surviving husband). Presumably, the owner of premises subject to a duty could recover from a surviving spouse or parent though there appears to be no authority on point.

${ }^{161}$ See, e.g., Routtu v. Routtu. supra note 151 (son): Tkachuk v. Uhryn. 6 W.W.R. 515 (Sask. Dist. C. 1952) (daughter); Bradshaw v. Beard, supra note 151 (brother); Ambrose v. Kerrison. supra note 68 (distant relative). Some strangers may, of course. have a duty to act. See supra note 155. And see Gladstone v. Murray Co.. 314 Mass. 584. 50 N.E. 2d 958 (1914) (corporation in which deceased held shares); Cape Girardeau Bell Telephone Co. v. Hamil, 160 Mo. App. 521, 140 S.W. 951 (1911) (cmployer). And see generally Annot., 35 A.L.R. 2d 1399 (1954).

${ }_{162}$ Rogers v. Price. 3 Y. \& J. 28. 148 E.R. 1080 (Ex. 1829); Davey v. Rural Municipality of Cornwallis. supra note 157: McDougall \& Broun Lid. $\checkmark$. Breckon. supra note 158 . 
Although it has occasionally been suggested that liability in these cases is premised on an implied request, ${ }^{163}$ it is clear that the remedy is imposed by law in the absence of any manifestation of express or implicd consent. ${ }^{164}$ The obvious desirability of prompt action and the impracticability, in many cases, of communication with the executors provide a rationale for the granting of relief even though the intervention is unrequested. Thus in Davey $v$. Rural Municipality of Cornwallis, ${ }^{165}$ a plaintiff who, without having been requested to do so, had buried an unidentified body, was allowed recovery against the defendant municipality, the latter being under a statutory duty to make such arrangements. On behalf of the Manitoba Court of Appeal, Robson J.A. noted that "the liability was enforced although there was no prior contract and, obviously. because of the necessity of the circumstances". ${ }^{166}$

The plaintiff must not have acted officiously in the place of a more appropriate party. ${ }^{\mathbf{1 6 7}}$ Again, reimbursement would not be allowed if the expenditures had been intended as a gift. ${ }^{168}$

\section{Fulfilment of Another's Duty to Support a Spouse or Children}

\section{(a) The Duty to Support a Spouse}

The duty of a husband to support his wife was recognized at common law. However, since the common law did not permit actions between husband and wife, the duty could only be indirectly enforced by the wife through her ability to pledge her husband's credit. ${ }^{169}$ As indicated previously, though her ability to do so is often rationalized in terms of agency of necessity, ${ }^{170}$ the third party supplier's claim against the husband is better viewed as being restitutionary in nature.

${ }^{163}$ See, e. g., Rees v. Hughes, supra note 152, at 527, [1946] 2 All E.R. at 52 (per Tucker L.J.).

${ }^{164}$ The earlier cases clearly indicate that the obligation is imposed in order to reimburse one who has, in necessitous circumstances, discharged the duty of the defendant. See, e.g., Jenkins v. Tucker, supra note 151, at 93, 126 E.R. at 57 (per Lord Loughborough).

${ }^{165}$ Supra note 157.

${ }^{166} I d$. at $262,[1931] 2$ D.L.R. at 83.

${ }^{167}$ See Patterson v. Patterson, 59 N.Y. 574, at 583, 17 Am. Rep. 384, at 392 (1875); Quin v. Hill, 4 Dem. 69 (N.Y. Surr. Ct. 1886) (intermeddling parent). And see generally Hope, supra note 120 , at 44 et seq.

${ }_{168}$ Coleby v. Coleby, L.R. 2 Eq. 803, 14 L.T. 697 (V.C. 1866).

${ }^{169}$ Right House Ltd. v. Esseltine, [1951] O.W.N. 871 (C.A.); Hughes v. Recs, 10 P.R. 301 (Ont. Master 1884), rev'd on other grounds 9 O.R. 198 (Ch. D. 1885); Biberfeld v. Berens, [1952] 2 Q.B. 770, [1952] 2 All E.R. 237 (C.A.): Eastland v. Burchell. supra note 55; Read v. Legard, 20 L.J. Exch. 309, 155 E.R. 698 (1851); lles v. Iles, 145 L.T. 71, 47 T.L.R. 396 (P.D.A. 1931); Manby v. Scott. I Sid. 109. 82 E.R. 1000 (Ex. Ch. 1663). In England, however, the wife's ability to borrow or pledge credit "as agent of necessity" has been abolished. See the Matrimonial Proceedings and Property Act 1970 , U.K. 1970, c. 45, s. 41 . In Ontario, the doctrine stricto sensu has been abolished, but an implied authority to pledge credit during cohabitation has been retained. See The Family Law Reform Act, 1978, S.O. 1978, c. 2, s. 33.

${ }^{170}$ See text accompanying notes 53-56, supra. 
A statutory duty of support is now a common feature of matrimonial causes statutes. ${ }^{171}$ Indeed, recent reforms have imposed reciprocal duties of support on both husband and wife, ${ }^{172}$ and have extended this obligation to "spouses" who, though unmarried, have cohabited for a specified period of time. ${ }^{173}$ It may be then, that the duty to support a spouse in need will be fulfilled by compliance with the terms of an award enforcing a statutory duty of support. Where this has not occurred, however, it is possible that situations of necessitous intervention could arise in which the intervenor should be permitted a restitutionary claim. ${ }^{174}$

\section{(b) The Duty to Support Children}

At common law, a father had no direct legal duty to provide support for his children. ${ }^{175}$ Although it was often stated that he was under a moral obligation to do so, the only recognition given this duty was quite indirect. It was accepted that the wife's ability to pledge her husband's credit extended to cover expenses incurred in supplying necessaries to minor children of the marriage, of whom she had custody. ${ }^{176}$

An enforceable parental duty of support has been created by statute. It is an offence under the Criminal Code for a parent, in certain stipulated circumstances, to fail to provide necessary support for a child under the age of sixteen years. ${ }^{177}$ Further, explicit duties of support and appropriate enforcement mechanisms are commonly found in modern matrimonial causes and child protection statutes. ${ }^{178}$ Additionally, of course, various

${ }^{171}$ See generally MacDougall, Alimony and Maintenance, in STUdIES IN CANADIAN FAMILY LAW, supra note 150 , at 283 et seq.

${ }^{172}$ See, e.g., The Family Law Reform Act, 1978, S.O. 1978, c. 2, s. 15.

${ }^{173}$ The Family Law Reform Act, 1978, S.O. 1978, c. 2, s. 14(b).

${ }^{174}$ See, Restrtution, supra note 4, at ss. 113-14. And see PALMER, supra note 4, s. 10.4, at 377-79. In jurisdictions such as England in which the deserted wife's agency of necessity has been abolished and in which it has been assumed that this doctrine supplied the rationale for the husband's liability to suppliers of necessaries, the granting of restitutionary relief may be considered to be inconsistent with the statutory reform. $C f$. The Family Law Reform Act, 1978. S.O. 1978, c. 2, s. 33. which appears to invite the same interpretation. And see Ontario Law Reform Commission. Report on Family LAw, PART VI, Support Obligations 133-35 (1975).

${ }_{175}$ Cleaver v. Cleaver, [1949] O.W.N. 640, [1949] 4 D.L.R. 367 (C.A.); Childs v. Forfar, 51 O.L.R. 210, 67 D.L.R. 17 (C.A. 1921); Wright v. McCabe, 30 O.R. 390 (Div`I Ct. 1898); Coldingham Parish Council v. Smith, [1918] 2 K.B. 90, 87 L.J.K.B. 816 (1917); Mortimore v. Wright, 6 M. \& W. 482, 151 E.R. 502 (Exch. of Pleas 1840). Contra, Nicole v. Allen, 3 C. \& P. 36, 172 E.R. 312 (K.B. 1827). And cf. Bazeley v. Forder, L.R. 3 Q.B. 559, at 564 (1868) (per Blackburn J.); Urmston v. Newcomen, 4 A. \& E. 899, 111 E.R. 1022 (K.B. 1836).

176 Bazeley v. Forder, supra note 175 . The issue as to whether a third supplier could recover from the husband without invoking the wife's agency of necessity was left open in Urmston v. Newcomen, supra note 175.

${ }^{177}$ R.S.C. 1970 , c. C-34, s. 197.

${ }^{178}$ See, e.g., The Family Law Reform Act, 1978, S.O. 1978, c. 2, ss. 16 \& 18. See also s. 17, which imposes a duty on children who are not minors to provide support for their parents. See generally MacDougall, supra note 171, at 344 et seq. 
publicly funded agencies may provide support to children in need. ${ }^{170}$ The occasions on which third party intervention will be necessary may, therefore, be somewhat rare, but it is possible to conceive of situations, as where immediate medical attention is required, in which restitutionary recovery may be awarded to an unofficious intervenor. ${ }^{180}$ Apart from such cases of urgent necessity, however, it seems unlikely that an intervenor could establish that his conduct was unofficious unless an attempt had been made to communicate with the parents in order to establish whether, save this intervention, the child's needs would not be met by the parents or by some other more appropriate party. ${ }^{181}$

\section{Fulfilment of the Statutory Duty of Another to Act in the Public Interest}

\section{(a) Public Authorities}

We have seen that one who intervenes in necessitous circumstances to fulfil the duty of a public authority to bury the dead may seek indemnification on restitutionary principles. ${ }^{182}$ This rule appears to be capable of extension to other situations in which there is an immediate need to take action to preserve public health or safety, action which would otherwise be undertaken by a public agency in discharge of a duty imposed by statute. Similarly, it may be appropriate to award relief where the failure or refusal of a public agency to discharge its duty gives rise to a situation of emergency to which a stranger responds.

Frequently, for example, a statutory duty is imposed on municipalities to provide medical assistance to indigent persons. ${ }^{183}$ An early English authority held that a stranger who intervened "under pressure of immediate want" to supply medical assistance to an indigent person could recover from the parish officers whose duty to supply such services had thus been fulfilled. ${ }^{184}$ There is ample American authority 10 the same effect. ${ }^{185}$ And, though there are a number of Saskatchewan

${ }^{179}$ Such agencies may be given a statutory right of reimbursement against the party owing the duty of support. See, e.g., The Family Law Reform Act, 1978, S.0. 1978, c. 2, s. $18(3)$.

${ }^{180} C f$. Urmston v. Newcomen, supra note 175. American authority permits recovery for necessaries supplied. See, e.g., Baker v. Baker, 169 Tenn. 589. 89 S.W. 2d 763 (1935); De Brauwere v. De Brauwere, 203 N.Y. 460, 96 N.E. 722 (Ct. App. 1911); Porter v. Powell, 79 Iowa 151, 44 N.W. 295 (1890); Pretzinger v. Pretzinger, 45 Ohio St. 452, 15 N.E. 471 (1887); Greenspan v. Slate, 12 N.J. Super. 426, 97 A. 2d 390 (1953); Van Valkinburgh v. Watson, 13 Johns. 480, 7 Am. Dec. 395 (N.Y. 1816). And see generally PALMER, supra note 4, s. 10.4, at 379-81.

${ }^{181}$ See Restitution, supra note 4, at ss. 113-14. And see Greenspan v. Slate. supra note 180 (holding, on close facts, that the immediacy of the medical emergency obviated the need to contact the parents).

182 Davey v. Rural Municipality of Cornwallis, supra note 157.

${ }^{183}$ See, e.g., The Public Health Act, R.S.O. 1970, c. 377, s. 56.

${ }^{184}$ Simmons v. Wilmott, 3 Esp. 91, 170 E.R. 549 (C.P. 1800).

${ }^{185}$ See Woodward, supra note 133, at s. 204; Annot., 93 A.L.R. 900 (1934). 
decisions denying relief in such circumstances. ${ }^{186}$ surely the better view is that liability on restitutionary principles may be imposed. ${ }^{187}$ Indeed, as has been suggested above. ${ }^{188}$ this appears to be the proper explanation for the result in cases such as Hastings 1 . Village of Semans ${ }^{189}$ which have imposed liability on the basis of strained applications of the agency of necessity doctrine.

Though it seems appropriate to compensate the suppliers of such services who have acted in an emergency. a right to restitution ought not to arise in situations where it was practicable to communicate with the public agency and the supplier did not do so. ${ }^{190}$ Such interventions are officious. However. where the agency is unable to respond to the emergency or refuses to do so, the intervenor s conduct is unofficious and should provide a basis for recovery. ${ }^{191}$

Apart from cases of medical necessity, it is arguable that restitutionary relief ought to be available to those who discharge a public agency's duty to take measures to preserve the safety of the public. In Holborn Union 1 . Vestry of St. Leonard. ${ }^{192}$ for example, a local authority failed to discharge its statutory duty to remove dust and ashes from a workhouse owned by the plaintiff. The plaintiff was permitted recovery of the costs it incurred in carrying out this task. The plaintiff had acted properly to protect the health of the inmates and. said Mellor J.. "it would be

${ }^{186}$ Jackes v. Village of St. Walburg. $[1931] 3$ W.W.R. 534 (Sash C A.): Sutherland v. Rural Municipality of Canwood. [1925] 3 W.W.R. 781 (Sask. Dist. C.). See also Black v. Rural Municipality of Edenwold. [1930] 3 W. W. R. 529. [1931] । D L R. 577 (Sask. C.A. 1930). The latter case. however. ought not to be viewed as one of necessttous intervention. as the plaintiff supplied services over a considerable pernod of tume without attempting to communicate with the defendant.

${ }_{187}$ The decision of the Supreme Court of Canada in Counly of Carletion 、 Cily of Ottawa. supra note 7. establishes that liabilits may be imposed on a municipality on unjust enrichment grounds where the services have been unofficiously supplicd by a plasnuff acting under a mistake. It follows from this decision. and indeed from general principle, that one who has acted unofficiously in an emergency may invoke a restututionary theory of liability.

Case law in the western provinces has narrouly interpreted applicable statuton provisions so as to deny recovery in cases where the statutory requirement of a written order has not been met. See Wagner v. Municipal Dist. of Pine Lake. |1931] 2 W' W R 481. [ 1931] 4 D.L.R. 258 (Alta. C.A.): Rose v. Rural Municipality of Blaıne Lahe. [1935] 3 W.W.R. 15 (Sask. Dist. Ct.). Insofar as these decisions may be viewed as support for the broader proposition that municipalities are. in principle. immune from restllutsonary liability for benefits of this kind. they cannot survive County of Caricton v City of Ottana ${ }^{188}$ See text accompanying notes 57-59. supra.

${ }^{189}$ Supra note 57. See also Irvine v. Parish of Stanley. 37 N.B.R. 572 (C.A. 1906); Coles v. Rural Municipality of Wawken, [1928] 3 W.W.R. 532 (Sask. Dist. C.), aff d [1929] I W.W.R. 663, [1929] 4 D.L.R. 1071 (Sask. C.A.).

${ }_{190}$ Noble County v. Niemann. 182 Okla. 497. 78 P. 2d 672 (1938): Burnham v Lincoln County, 128 Neb. 47. 257 N.W. 491 (1934). Cf. Black v. Rural Mlunicipality of Edenwold. supra note 186.

${ }^{191}$ Noble County v. Niemann. supra note 190. The point was ralsed and left unanswered in Sutherland v. Rural Municipality of Canwood, supra note 186 1922 Q.B.D. 145.46 L.J.Q.B. 36 (1876). 
unreasonable to hold that the duty cast upon [the defendants] can be enforced only by indictment or mandamus". ${ }^{193}$ Consider, further, the claim of one who repairs a road or bridge in dangerous condition after the responsible municipality has refused to do so. Such claims find support in the Restatement ${ }^{194}$ and are consistent with general principle, but are not likely to arise in practice as public authorities, when contacted, are prone to act swiftly in such matters, if only to avert potential liability for injuries resulting from the state of disrepair. ${ }^{195}$

A more general right to intervene in the public interest has been tested in the American case law, primarily in the context of claims brought by parents who have discharged the statutory duty of a school board to provide school transportation for their children. In a number of such cases, relief has been awarded. ${ }^{196}$ The underlying principle was stated in Sommers v. Putnam County Board of Education ${ }^{197}$ in the following terms:

The obligation must be of such a nature that actual and prompt performance thereof is of grave public concern; the person upon whom the obligation rests must have failed or refused with knowledge of the facts to perform the obligation; or it must reasonably appear that it is impossible to perform it; and the person who intervenes must, under the circumstances, be not a merc intermeddler but a proper person to perform the duty. ${ }^{198}$

Although it may be doubtful that Canadian courts would extend recovery beyond the obvious cases of peril to physical health and safety, the American school transportation cases do indicate that there may be other situations in which the intransigence of a public authority may give rise to a situation of grave public concern in which unofficious intervention would merit restitutionary relief.

A limiting factor in these cases may arise from a concern 10 discourage intervention by private parties which might impair the ability of public authorities to exercise a discretion to determine the level and timing of their expenditures in the light of their own perception of the public

\footnotetext{
${ }^{193}$ Id. at 149,46 L.J.Q.B. at 38.

${ }^{194}$ Restitution, supra note 4, at s. 115, Comment b. But see Macclesfield Corp. v. Great Cent. Ry., [1911] 2 K.B. 528, 104 L.T. 728 (C.A.).

${ }^{195}$ Although the municipality's conduct may amount to non-actionable nonfeasance at common law, a statutory liability for damages sustained by reason of failure to repair is commonly imposed by statute. See, e.g.. The Municipal Act, R.S.O. 1970, c. 284, s. 427. $C f$. French v. Lew is and Clark County, 87 Mont. 448, 288 P. 455 (1930), noted in 29 MiCH. L. Rev. 119 (1930) (permitting recovery even though the repairs did not appear to be a matter of urgency).

${ }^{196}$ Rysdam v. School Dist. No. 69, 154 Or. 347, 58 P. 2d 614 (1936): Sommers v. Putnam County Bd. of Educ., 113 Ohio St. 177, 148 N.E. 682 (1925); Eastgate v. Osago School Dist., 41 N.D. 518, 171 N.W. 96 (1919). Contra, Bruggeman v. Independent School Dist. No. 4, 227 Iowa 661, 289 N.W. 5 (1939). In Halliday v. Marchington. 44 Ohio App. 132. 184 N.E. 698 (1932), it was held that the plaintiff ought to exhaust his administrative remedies before supplying the transportation. See also Noble v. Williams. $150 \mathrm{Ky} .439,150$ S.W. 507 (1912) (teachers who paid expenses of running a school denied recovery).

${ }^{197}$ Supra note 196.

${ }^{198}$ Id. at 184,148 N.E. at 684.
} 
interest. Such concerns could not weigh heavily in situations of immediate peril to public health and safety; nor should they, I would argue, in other situations where prompt intervention is in the public interest, where official intransigence or incapacity has been established, and where the intervenor is an appropriate person to discharge the duty in question. In the absence of such considerations, or in situations where the lack of a clearly defined statutory duty suggests that a broad discretion has been conferred on the public authority to determine whether or not to act, it would be appropriate to discourage intervention and to restrict the aggrieved citizen to such redress as is available through the usual mechanisms of indictment, mandamus ${ }^{199}$ and the political process.

\section{(b) Others}

Apart from cases of substitutional performance of what are now commonly statutory duties of support, considered above, it is conceivable that statutory duties may be imposed on individuals or non-governmental corporate entities to carry out undertakings in the public interest. Again, where the breach of such a statutory duty creates a situation of imminent peril to public health or safety, it is consistent with principle that one who, being a proper person to do so, intervenes to avert the hazard should be entitled to recover in restitution. It may often be that a public authority is the most appropriate party to intervene and, where this is the case, it may be argued that it would be officious to intervene without first inviting the public authority to do so unless, of course, timely communication with the authority is impracticable. Where the public authority does intervene, however, it would appear to have an especially compelling argument for relief. Nonetheless, in Macclesfield Corp. v. Great Central Railway ${ }^{200}$ the English Court of Appeal rejected a claim brought in a situation of this kind. The defendant railway company was subject to a statutory duty to keep a certain bridge roadway in repair. The bridge having fallen into disrepair and become dangerous, the plaintiff, the highway authority for the district, requested the defendant to carry out its statutory duty. Upon the latter's refusal, the plaintiff undertook the repairs and claimed the costs of so doing. The court held that the plaintiff, being under no legal obligation to act, was a volunteer and therefore not entitled to recover.

The Macclesfield case thus provides an impediment to necessitous intervention claims in this category of situations. The case might be distinguished on the basis that a restitutionary claim was apparently neither pleaded nor considered. Or one might agree with Woodward's rather more

199 On the availability of mandamus, see generally S.A. DE SMITH, JUDICIAL REVIEW OF ADMINISTRATIVE ACtION 480-505 (3d ed. 1973). It appears that mandamus is not available to compel a municipality to discharge its duty to maintain roads, it being suggested that indictment is the proper course. See,e.g. . Cummings v. Town of Dundas, 13 O.L.R. 384 (Div'l Ct. 1907); Nobel v. Rural Municipality of Turle Mountain, 15 Man. R. 514, 2 W.L.R. 144 (K.B. 1905).

${ }^{200}$ Supra note 194. 
blunt assessment that the decision is simply erroneous. ${ }^{201}$ In my view, Macclesfield is clearly inconsistent with the restitutionary principles manifested in the necessitous intervention case law and ought not to be followed. Support for this view can be drawn from a line of American authority permitting recovery by public authorities in circumstances of this kind. ${ }^{202}$

\section{Response to an Emergency Created by Another's Breach of a Common Law Duty in Tort or Contract}

\section{Tort}

When a stranger intervenes to render necessary services to a victim of tortious conduct, a situation arises which is tantalizingly analogous to the previously considered instances of discharge of another's duty. A road accident resulting in physical injury, for example, may lead to the intervention of friends, relatives or strangers to provide needed assistance to the victim. A physician may supply medical care, a neighbouring municipality may provide firefighting or other rescue services, friends or relatives may provide support during convalescence. The need for such services arose as the direct result of the tortfeasor's breach of his common law duty. He could be held liable for the cost of most, if not all, of these services in the victim's action in tort. May one not argue, therefore, that the supply of such services confers a benefit on the tortfeasor at the supplier's expense for which a direct action by the supplier against the tortfeasor should be allowed?

In a recent Ontario case, it has been suggested that such a claim may be possible. In Attorney-General for Ontario $v$. Crompton, ${ }^{203}$ firemen from a neighbouring municipality were summoned to the scene of an accident which had occurred on a provincial highway as a result of the defendant's negligence. The firemen extinguished a fire and rescued an occupant from one of the cars involved. Both the municipality and the province sued the tortfeasor for the cost of the services rendered by the municipality, the municipality pleading its case on several grounds, onc of which was unjust enrichment. The municipality's claim failed as it had been fully compensated for its services by the province pursuant to an agreement with the province to provide services of this kind. Had there not been such an agreement, said Haines J., the municipality could have succeeded in restitution on the basis of the necessitous intervention casc law. ${ }^{204}$ In my view, such a cause of action should be recognized only in a very limited range of situations.

201 WoODWARD, supra note 133, at 334-35.

202 Wyandotte Transp. Co. v. United States, 389 U.S. 191, at 204, 19 L. Ed. 2 d 407. at 416-17 (1967); United States v. Boyd, 520 F. 2d 642 (6th Cir. 1975), cert. denied. 423 U.S. $1050,96 \mathrm{~S}$. Ct. 776 (1976) (removal of sunken vessels creating a hazard to navigation).

${ }^{203} 14$ O.R. (2d) 659, 74 D.L.R. (3d) 345 (H.C. 1976).

${ }^{204} I d$. at 662,74 D.L.R. (3d) at 348, citing Matheson v. Smiley, supra note 74 . in support. 
In cases of this kind, where the victim has not been required to pay for the services rendered to him, the difficult question is whether the tortfeasor or the intervenor (or, perhaps, the victim) will ultimately bear the burden of the expense involved in their supply. It may be that the most straightforward analysis of this question would result if the victim were, as a general rule, precluded from claiming as damages in tort the value of benefits received for which he has not paid and, further, if the question of allocating the burden of these costs as between the supplier (the "collateral source") and the tortfeasor were to be determined in a direct claim by the former against the latter for indemnification of the expense which he has saved the tortfeasor by his intervention. For reasons which need not be elaborated here, our law has not followed this pattern. Under present law, the liability of the tortfeasor to bear such costs is normally tested in the victim's claim against the tortfeasor through application of the collateral source rule. ${ }^{205}$ Further, the ability of the collateral source to recoup the value of the benefit conferred will normally be ascertained through the application of subrogation doctrine ${ }^{206}$ or through a direct claim against the victim. ${ }^{207}$ The combined effect of these liability rules is to treat the position of the collateral source as a derivative of the victim's rights against the tortfeasor and to resolve, in this indirect fashion, the question of whether the tortfeasor or the collateral source must bear the cost of the latter's intervention. In the rare instances in which a direct claim for reimbursement has been brought against the tortfeasor, it has usually failed. ${ }^{208}$

${ }^{205}$ See generally FLEMING, supra note 51 , at 224-31.

${ }^{206}$ See generally GOFF AND JONES, supra note 6, at 406-45; PALMER, supra note 4, ch. 23, at 436-76. Subrogation doctrine may permit the collateral source to enforce the victim's rights against the tortfeasor or, where the victim has already successfully recovered in tort, to bring a claim against the victim for reimbursement.

${ }^{207}$ The collateral source may have a contractual right against the victim. Alternatively, where the intervention, though unrequested. amounts 10 a necessitous intervention, recovery should be allowed in restitution. Here one relies by analogy on Matheson v. Smiley, supra note 74. See also Birks, Restiutuion for Service's. 27 CURRENT LEG. PROB. 13, at 33-35 (1974). Occasionally. in cases where the collateral source has not actively asserted a claim against the victim. a result consistent with this view has been achieved by the imposition of a condition on the victim's award from the cortfeasor that the victim reimburse the collateral source. See, e.g.. Coderre v. Ethier. 19 O.R. (2d) 503, 85 D.L.R. (3d) 621 (H.C. 1978); Myers v. Hoffman, [1955] O.R. 965, I D.L.R. (2d) 272 (H.C.); Schneider v. Eisovitch, [1960] 2 Q.B. 430, [1960] I All E.R. 169 (1959); Dennis v. London Passenger Transp. Bd., [1948] I All E.R. 779, 64 T.L.R. 269 (K.B.). But see Blundell v. Musgrave, 96 C.L.R. 73 (H.C. 1956). Lord Denning M.R. has proposed as a solution to these problems that the victim be deemed to hold that portion of the award which reflects the value of the service rendered by the collateral source in trust for the latter: Cunningham v. Harrison. [1973] I Q.B. 942. at 952. [1973] 3 All E.R. 463. at 469 (C.A.).

${ }^{208}$ Porter v. Grand Trunk Pac. Ry.. [1919] I W.W.R. 988, 45 D.L.R. 749 (Alta. C.A.); Receiver for the Metropolitan Police Dist. v. Croydon Corp., [1957] 2 Q.B. 154, [1957] 1 All E.R. 78 (C.A. 1956), rev'g [1956] 2 All E.R. 785 (Q.B.), aff g, sub nom. Monmouthshire County Council v. Smith. [1956] 2 All E.R. 800 (Assizes). This case overruled Receiver for the Metropolitan Police Dist. v. Tatum. [1948] 2 K. B. 68, [1948] 1 All E.R. 612. 
As a general matter, this derivative analysis of the position of the collateral source seems preferable to the mechanism of a direct restitutionary claim against the tortfeasor for a number of reasons. The tortfeasor will be spared a multiplicity of lawsuits. The compromise of tort claims will be unencumbered by difficult calculations of potential direct liabilities to collateral sources. Moreover, the derivative approach forces the parties to bring on the tort claim and thus clearly establish the extent of the tortfeasor's liability. If the tortfeasor's liability in tort is not in fact tested by the victim, the benefit conferred on the tortfeasor may appear to be rather chimerical. A successful restitutionary claim would hold him liable for the reduction of a potential liability which never did, in fact, accruc. Further, under existing rules, if the tort liability is tested by suit, the tortfeasor (unless saved by an exception to the collateral source rule) will be held liable for the cost or value of the supply of items rendered necessary by his tortious conduct. If this occurs, of course, it can no longer be maintained that the tortfeasor has been unjustly enriched.

Hard cases may arise, however, in circumstances where an exception to the collateral benefit rule excuses the tortfeasor from liability with respect to the cost or value of the benefit in question. The issue between the victim and the tortfeasor may not be formulated as one of unjust enrichment of the tortfeasor at the expense of the collateral source, but rather as one of determining whether the victim should be compensated for an expense which he has not incurred. ${ }^{209}$ If the latter approach is adopted, denial of recovery in tort may create a situation in which the tortfeasor has, in some sense, profited at the supplier's expense. In Porter v. Grand Trunk Pacific Railway ${ }^{210}$ a physician claimed for medical and hospital services supplied to four labourers injured as a result of the defendant's negligence. 'The victims' employer had established a hospital (financed by employee wage deductions) which was under the control and direction of the plaintiff. After the workmen were admitted to the hospital, the plaintiff sent a telegram to the tortfeasor, indicating that the necessary treatment would be rendered "at your expense". In the tort action brought by the labourers, a claim was made for the value of the medical services. Although the action was generally successful, this particular item was disallowed. Accordingly, the physician, alleging that he had not been paid for the services rendered, thereupon brought his own claim for indemnification against the tortfeasor, arguing that a contract to indemnify could be implied from the tortfeasor's failure to reply to the telegram. ${ }^{211}$ This argument failed and the physician's claim was dismissed. What would appear to be an unjust enrichment of the tortfeasor here could occur in other situations where the value of benefits received from a collatcral source is not allowed as a head of damage in the tort claim. Thus if, as has

${ }^{209}$ See generally Fleming, supra note 51, at 224-31.

210 Supra note 208.

211 The claim was founded in contract rather than restitution. as the contract was alleged to be one which could be inferred from certain conduct of the parties. 
occasionally been suggested, ${ }^{212}$ the value of necessary services supplied, apparently gratuitously, by relatives and friends (who may endure financial costs in so doing) cannot be claimed by the victim. it seems unjust that the tortfeasor should profit from this benevolence. Nonetheless, direct claims against tortfeasors by donors have been denied. ${ }^{213}$

Further, we may note that although timely intervention on subrogation principles may avoid injustice in some of these cases, the availability of the subrogation remedy will turn on the nature of the relationship between the collateral source and the victim, and will not be invariably available simply because the tortfeasor will otherwise be enriched at the expense of the collateral source. ${ }^{214}$ Moreover, the denial of subrogation may reflect, in some instances, a determination that the collateral source (being, for example, an institution in the business of distributing risks) is the appropriate party to bear the risk. ${ }^{215}$ In such cases, arguably, the enrichment of the tortfeasor is not unjust.

In sum then, the interaction of the existing tort and subrogation rules will often yield a result which will prevent an unjust enrichment of the tortfeasor at the expense of the collateral source. Yet this may not be, in every situation, a conscious objective of the analysis. Accordingly, there is some risk that an unjust enrichment may occur. The Porter case ${ }^{216}$ illustrates this phenomenon. In such situations, the cause of action suggested by Haines $\mathbf{J}$. would usefully fill a lacuna in the existing remedial framework. ${ }^{217}$ It is suggested, however, that in order to avoid conflict with

${ }^{212}$ See, e.g., Haggar v. de Placido. [1972] 2 All E.R. 1029, [1972] I W.L.R. 716 (Chester Crown Ct.), noted in 88 L.Q.R. 323 (1972) and overruled by Donnelly v. Joyce, [1973] 3 All E.R. 475, [1973] 3 W.L.R. 514 (C.A.), nored in [1974] CAMB. L.J. 40.

Proposals of the English Law Commission which would put the matter beyond chance and allow the victim to recover the value of reasonable expenses gratuitously incurred by others or the reasonable value of necessary services gratuitously supplied have not, as yel. been acted upon by Parliament. See The Law Commission. Report on Personal Injury Litigation - Assessment of Damages, LaW CoM. No. 56 paras. 112-14 (1973). It may be, however, that a liberal interpretation and application of the holding in Donnelly $v$. Joyce would provide a more comprehensive solution to this problem.

${ }^{213}$ See Rawson v. Kasman. [1956] O.W.N. 359, 3 D.L.R. (2d) 376 (C.A.): Admiralty Comm'rs v. S.S. Amerika, [1917] A.C. 38, 86 L.J.P.D. \& A. 58 (H.L. 1916).

In Ontario, recent family law reform legislation has conferred a cause of action on the spouse of the victim and on other members of the immediate family permitting recovery, inter alia, of the "actual out-of-pocket expenses reasonably incurred for the benefit of the injured person" and, where nursing, housekeeping or other services are supplied. "a reasonable allowance for loss of income or the value of the services". The Family Law Reform Act, 1978, S.O. 1978, c. 2, s. 60. See also Ontario Law Reform Commission. Report on Family Law, Part I, Torts ch. 10 (1969).

${ }^{214}$ See generally sources cited note 206 , supra.

${ }^{215}$ See generally Feldthusen, Pure Economic Loss Consequent upon Physical Damage to a Third Party, 16 Western ONt. L. Rev. 1, at $67-91$ (1977).

${ }^{216}$ Supra note 208.

${ }^{217}$ For an exploration of the possibility of a direct action in tort by the collateral source for the economic loss sustained as a result of the tort committed against the victim. see Feldthusen, supra note 215. Analogical suppon may be drawn from Ontario statutory 
the policies underlying the existing rules, two restrictions on the availability of this remedy should be recognized. First, it ought not to be available where the collateral source is adequately protected by the remedies available under established tort and subrogation doctrine. ${ }^{218}$ Secondly, a direct restitutionary claim ought not to succeed where the collateral source is, as against the tortfeasor, the appropriate party to distribute the risk which has accrued.

A variation on the factual pattern under consideration here suggests further possibilities for restitutionary analysis. Let us assume that a timely intervention has the effect of counteracting the negligence of a potential tortfeasor and thus prevents the accident from occurring. The intervenor has conferred a benefit on the negligent actor by forestalling potential tort liability. In these circumstances, the argument for restitutionary recovery is much more straightforward. There being no tort claim to be prosecuted, the granting of direct restitutionary relief does not risk conflict with the policy underlying subrogation or collateral source doctrines. Liability on this basis has not, however, been tested. ${ }^{219}$

\section{Contract}

Failure to perform a contractual duty to provide support to another may create an emergency to which a stranger to the agreement responds by providing the needed support. Restitutionary claims by such strangers against the defaulting promisors are reported in the American case law. The authorities are divided. ${ }^{220}$ The Restatement favours the view that

provisions which confer a direct right of action against the tortfeasor on relatives who have supplied benefits to the victim. See note 213 , supra. Interestingly, however, the Ontario provisions appear not to adopt the "derivative view" of the cause of action of the relatives argued here. The provisions do not explicitly preclude the possibility of both the victim and the relative bringing claims for the value of such benefits. Presumably, courts would prevent instances of double recovery by either denying compensation to the victim in cases where the relatives had already achieved success or, alternatively, by reading into the Statute an equivalent limitation on the cause of action conferred on the relatives.

${ }^{218} C f$. Donnelly v. Joyce, supra note 212 , at 480, [1973] 3 W.L.R. at 519-20 where Megaw L.J. suggests that as a corollary to the rule that the victim may claim in tort the value of gratuitously supplied benefits, the suppliers would have no direct action against the tortfeasor "unless at any rate some very special circumstances exist, such perhaps as the anomalous or anachronistic rules regarding loss of consortium or loss of services".

219 The point has been mooted by one American writer. Hope. supra note 120, at 40-41. See also PALMER, supra note 4, s. 10.6, at 409-10.

${ }^{220}$ For cases denying recovery, see Wilson v. Combs, 203 Miss. 286, 33 So. 2d 830 (1948); Richardson v. Richardson, 207 N.C. 314, 176 S.E. 744 (1934); Matheny v. Chester, 141 Ky. 790, 133 S.W. 754 (1911); Savage v. McCorkle, 17 Or. 42, 21 P. 444 (1889); Moody v. Moody, 14 Me. (2 Shep.) 307 (1837). For cases allowing recovery, sec In re Mach, 71 S.D. 460, 25 N.W. 2d 881 (1947), noted in 46 Mich. L. REv. 115 (1947), which held that a stranger who fulfilled a duty of support undertaken by a grantec in a conveyance of land was entitled to be subrogated to the grantor's equitable lien on the land: Henry v. Knight, 74 Ind. App. 562, 122 N.E. 675 (1919); Forsyth v. Ganson, 5 Wend. 558, 21 Am. Dec. 241 (N.Y. 1830). See also Annot., 31 A.L.R. 658 (1924), which reviews the case law concerning support obligations expressly charged against property. 
recovery be allowed and this may be supported on the basis of the necessitous intervention principle. ${ }^{221}$ The stranger in such a case has unofficiously conferred a benefit in the form of fulfilment of the defendant's contractual obligation.

\section{CONCLUSION}

An examination of the case law permitting recovery to the altruistic intermeddler across a broad range of factual situations thus yields considerable evidence in support of the view that the courts have accepted the validity of a general principle of necessitous intervention of which these individual instances of recovery are merely specific applications. The general principle is hedged with limitations which appear to ensure that recovery will not be permitted where the intervention is officious or where the conduct of the intervenor is not beneficial. Thus, recovery will be denied where it would have been practicable to seck consent to intervene, or where the intervenor should have deferred to a more appropriate party. The conduct of the intervenor must have been reasonable and must have been undertaken in the best interests of the benefited party. Further, recovery will not be permitted if the intervenor acted with the intention of making a gift of his services.

It is abundantly clear that the juristic basis of the necessitous intervention principle is neither contractual nor tortious. Although some of the earlier cases did suggest that relief is premised on an implied request for the intervention, it seems to be now well accepted that the obligation is one imposed by law. ${ }^{222}$ It is evident that these obligations are not imposed on the basis that the defendant's conduct is tortious. The remedy is made available simply to permit unofficious intermeddlers to recover the value of benefits conferred. Accordingly, it is properly categorized together with other instances of what are now recognized in Canada, as in the United States, to be applications of a more general principle of unjust enrichment. ${ }^{223}$

The one factual situation which has resisted resolution along these lines in the English and Canadian case law is necessitous intervention to preserve another's property. It is argued here that the apparent reluctance of the courts to grant such relief is an indefensible anomaly. It may well be that clear recognition of the unjust enrichment rationale underlying the

221 Supra note 4, at s. 114. The REST ATEMENT subsumes this situation together with cases of fulfilment of statutory duties within a general rule that one who performis the dury of another to supply necessaries is entitled to restitution provided that " the things or services supplied were immediately necessary to prevent serious bodily harm to or suffering by such person". This proviso is unduly restrictive, as there does not appear to be a reason grounded in public policy for refusing relief for the unofficious confertal of other kinds of needed goods and services.

${ }^{222}$ See, e.g., In re Rhodes, supra note 16: Matheson V. Smiley, supra notc 74

${ }^{223}$ The connection between the necessitous intervention casc law and the unjust enrichment principle seems to have been expressly adverted to by Laskin J.A. (as he then was) in Regina v. Howson, supra note 130. 
necessitous intervention cases may assist in the evolution of rules permitting recovery in such cases.

Finally, it must be emphasized that there is an historical overlap between the necessitous intervention principle and the extended and rather artificial application of the agency of necessity doctrine which has been described above. The suggestion made here is that the clarity of the analysis of these problems would be much enhanced if the operation of the agency of necessity doctrine were restricted to what has been termed above the true agency model. Cases involving a pre-existing relationship in which a power to deal with the unforeseen emergency can reasonably be implied into the terms of the agreement between principal and agent constitute the proper domain of the agency of necessity doctrine. Where such powers cannot realistically be inferred, the unjust enrichment analysis offers a more straightforward conceptual framework within which to assess the intervenor's claim. 